PAGES International Project Office Bärenplatz 2

$\mathrm{CH}-3011$ Bern

Switzerland

Tel: +41313123133

Fax: +41313123168

pages@pages.unibe.ch

Layout: Christoph Kull

Circulation: 3200

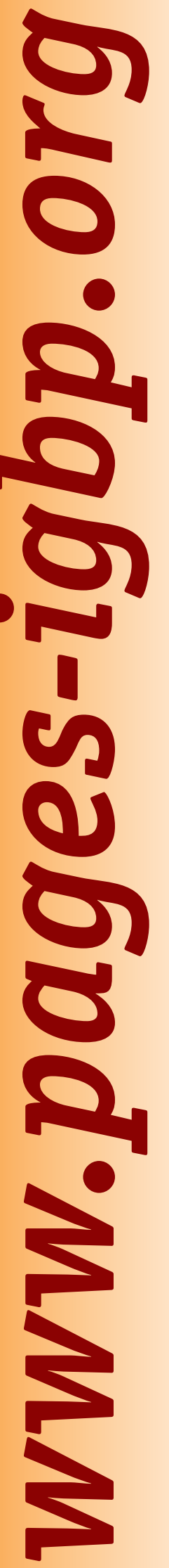

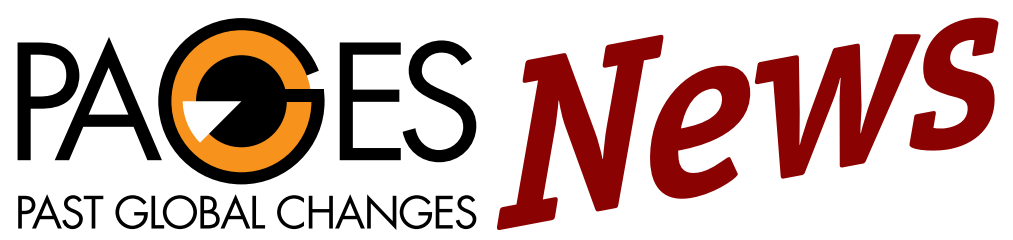

Christian Pfister and Heinz Wanner, Guest Editors Christoph Kull and Keith Alverson, Editors

Vol.10, $\mathbf{N}^{\circ} 3$ - Dec. 2002

\title{
Documentary Evidence
}

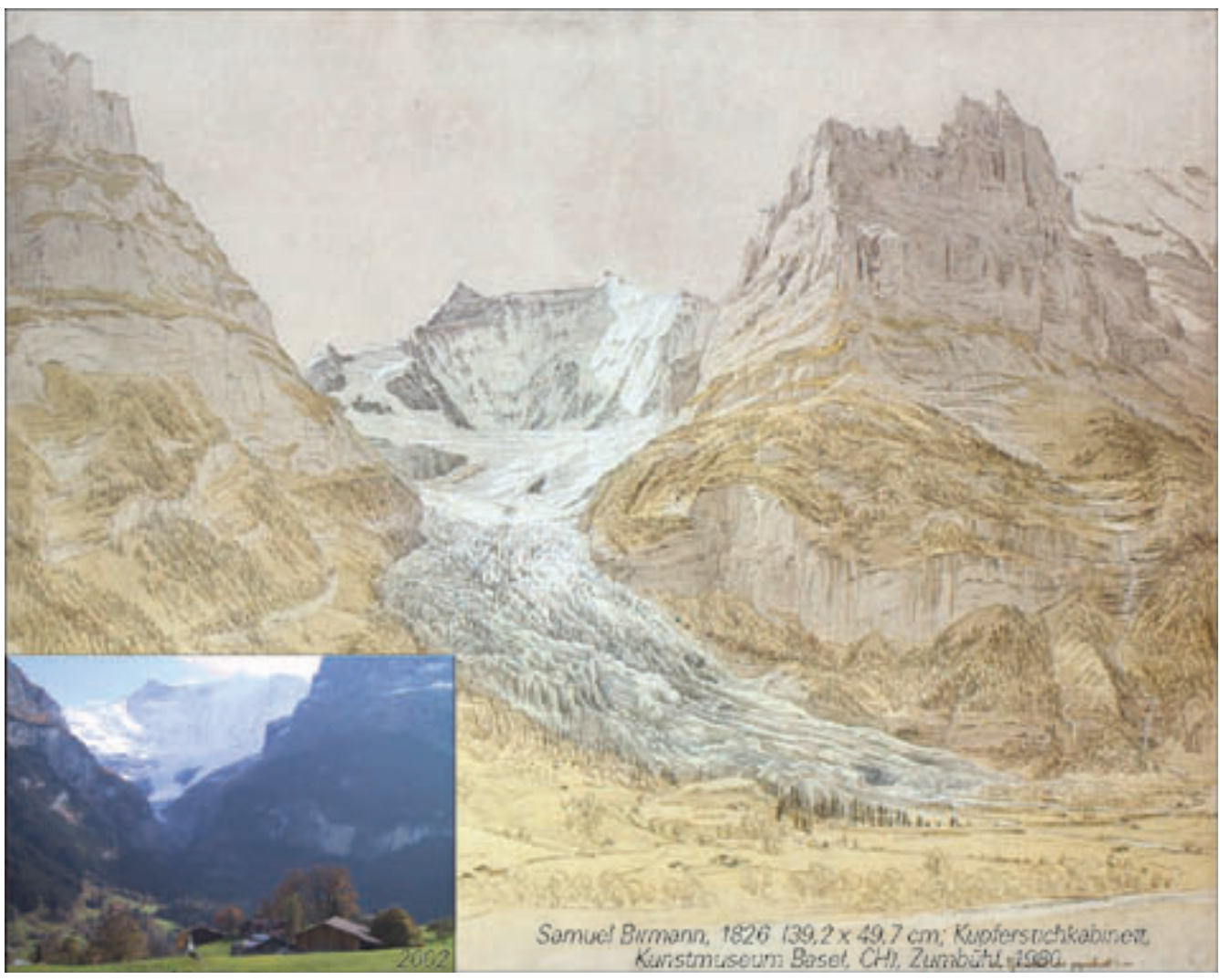

Tableau: The Lower Grindelwald glacier in 1826. Watercolored and gouached pencil drawing by Samuel Birmann. Small Photo: View from approximately the same position in 2002 (Photo: C. Kull). PAGES is looking for similar pairs of illustrations about global change for its image database. Please contact: kull@pages.unibe.ch

\section{Contents}

2 Announcements

- Editorial: Documentary Data

- Conferences: Upcoming PAGES Sessions

- Tales from the Field

- Inside PAGES

4 Program News

- LAMSCAN: Lake Sediments, Scandinavia

5 National Page

- USA

6 Science Highlights

- Documentary Data: An Overview

- LOTRED: Paleoreanalysis for Europe
- The Potential in Latin America

- ENSO Reconstructions in South America

- Temperature Reconstructions in Japan

- China: A 2000 Year Temperature History

- USA: Past Climate and Cyclones

- Floods in Europe

- Art and Climate

26 Workshop Reports

- Holocene Catastrophes and Recoveries

- Swiss NCCR-Climate Summer School

28 Last Page

- Calendar

- New on the PAGES Bookshelf 


\section{Announcements}

\section{Editorial}

Before the advent of instrumental records, up to 20 observations a day were carried out at specific sites, by the same observer, following defined rules. Despite this plethora of data, many scientists are of the opinion that observations made before the instrumental period are "subjective" and less reliable than natural proxies. But these data were collected by very experienced scientists and observers. Once calibrated and verified in the present, the data are precise and have a spatiotemporal resolution unmatched by any other climate proxy data. They are probably the best data source for the reconstruction of climatic state parameters in continental areas for the period between 1500 and 1850. In addition, a world-wide data base of daily information is being put together for the worlds major oceanic areas from naval logbooks (project CLIWOC). Natural disasters are a major source of societal concern in the context of climatic change. However, the record of instrumental measurements is too short to explore natural patterns of disasters. This also holds for investigations into societal vulnerability. In this context, documentary evidence is invaluable. This issue of PAGES News mirrors the fact that investigations on documentary data are unevenly distributed on the globe. On one hand, this distribution is related to the abundance and availability of the data sources, which, in China go back for several thousand and in Europe for several hundred years. On the other hand, this kind of research has until recently been somewhat neglected in the Americas, where written sources begin with the European settlement. In Australia and in Africa records are almost absent. Curiously, hardly any research has been devoted to the Islamic world, despite its long standing tradition of keeping annals. Dealing with documentary data requires a historian's skills. Scientists tend to overlook the pitfalls inherent in this data and are usually not familiar with old languages, institutions and hand-writing. On the other hand scientists are needed for statistical analysis and climatological interpretation of the data. Worldwide, many thousand volumes with daily observations exist, but have not yet been analyzed for their climatic information. Let's get to work!

Christian Pfister; Heinz Wanner

University of Bern, Switzerland christian.pfister@hist.unibe.ch; wanner@giub.unibe.ch

\section{Conferences}

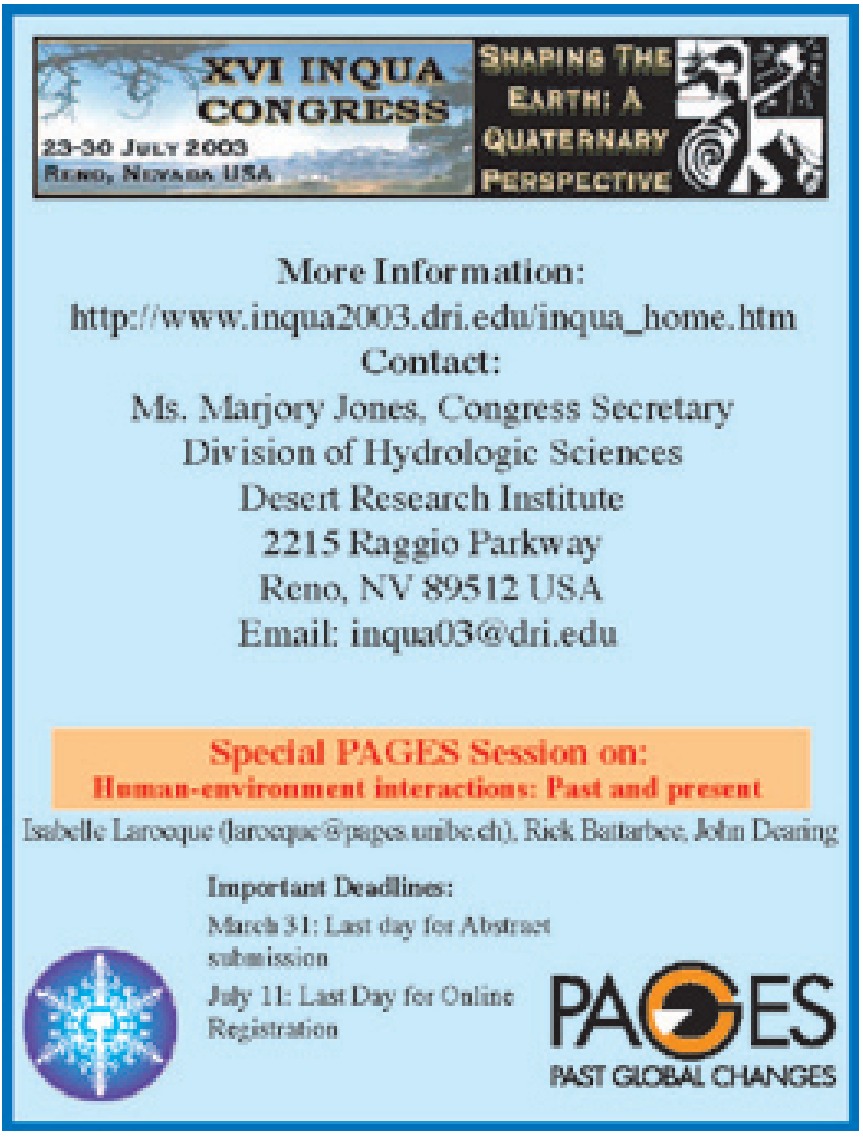

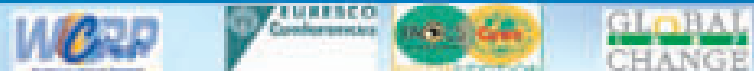 \\ Achieving Climate Predictability Using Paleoclimate Data}

11-16 October 2003 - San Feliu de Guixols, Spain

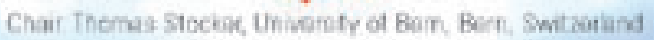

Whe-Chair Martin Vebeciz Lamoet-Denerty Eatn Ossatvanon, Faludes Short Synopsis:

It is contererce is tog tore

togatter ENo racesert

waisblity and

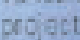

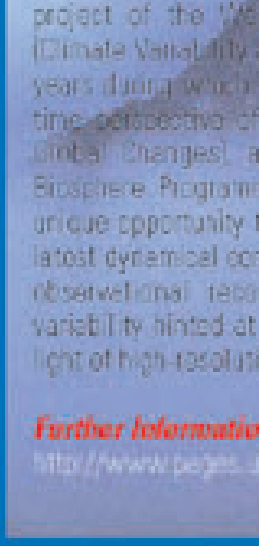




\section{Tales from the Field}

\section{Troubles come in threes}

1) There is a color transparency in my collection that shows me in swimming trunks on the edge of a small, very remote lake in the New Guinea Highlands with the end of an airline from a large compressed air cylinder taped into my nose. Not recorded is my attempt, so taped, and with the air trickling into my nose, to haul myself seven meters down the anchor rope in the centre of the lake in an abortive attempt to retrieve the remains of essential coring apparatus lodged at the bottom of the lake. Having assembled the equipment (a Mackereth Minicorer) on the lake-side, I had failed to check a vital coupling which had become detached from the retrievable part of the gear. Once I hauled up what I looked forward to enjoying as our first sediment core, I discovered that my haste had led to disaster. After two fruitless days of hunting for garages and Public Works Department depots with lathes I eventually resorted to making the coupling by sawing off the tops of the brass core caps with a junior hacksaw and spot weld- ing the remaining thread onto the corer.

2) We moved on to our next lake (Egari) with this rather delicately assembled apparatus only to discover that the local villagers, would not cooperate until we had spent a morning with their ace marksman who, with his bow and arrow, stood in our inflatable boat as we quietly rowed around the small crater lake looking for the freshwater crocodiles that an agricultural extension officer had put in the lake much to the disgust of the villagers. None was seen, but help was agreed and our coring went well.

3) The third contretemps came when I returned to resample the lakes and visit others six years later. A mishap suffered by an ANU expedition the previous year had led to the drowning of a local man and there was a problem of 'payback'. I therefore avoided using a boat and did all the coring by swimming out with a 'Russian Corer' and up to 4 maters of rod, while using the buoyancy of two life jackets to keep afloat. At the last lake we sampled, I had been assured that it was safe to go up to the crater and do our coring, so I happily swam out into the lake, life jackets in- flated and corer at the ready. I then looked up to see an arrow fly just above me. There were angry noises coming from the edge of the lake. I beat a hasty retreat to discover a rather vociferous, English speaking villager from the other side of the lake explaining that there was a battle on for possession of that area and didn't we know. Eventually he calmed our fears by reassuring us that they had given up fighting for the afternoon and we'd be OK. At that time, in 1979, fighting had sprung up all over the western and southern highlands and sadly, this turned out to be my last field work in the area.

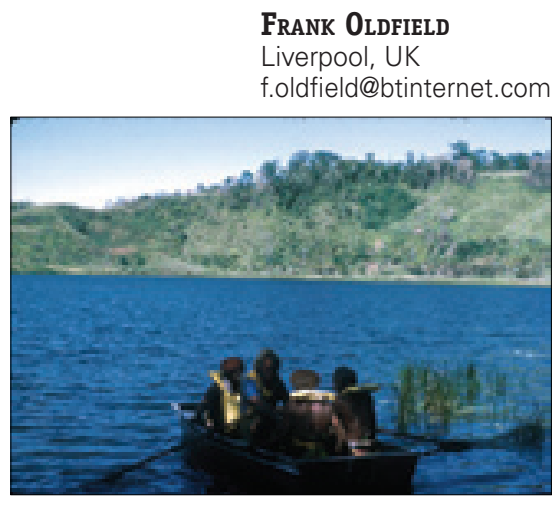

Fig. 1: Helpers from Egari village getting ready to look for fresh water crocodiles in the lake (Photo: F. Oldfield)

\section{Do you have an interesting and humorous story from your paleoenvironmental fieldwork? If you write it down in $\mathbf{5 0 0}$ words or less and send it to us, we will put it in PAGES news!}

\section{Inside PAGES}

The Pages IPO is undergoing some major staffing changes. Our office manager, Selma Ghoneim, began maternity leave in October and is not expected back in the office until March next year. Congratulations Selma! Selma's duties will be temporarily redistributed among the other office staff. Additionally, starting January 1, the IPO loses our science officer, Isabelle Larocque, who is returning to full time research. Isabelle did a great job at the IPO and we will miss her various skills. Isabelle will remain active in PAGES focus
5 and we hope maybe to entice her to return to Bern as a guest scientist some day. As a result of Isabelle's departure, Christoph Kull, currently our graphics coordinator, will take on additional official duties as science officer. In addition, beginning in June, Leah Christen-Witton, an Australian citizen resident in Bern with a background in science communication, will join us as to cover various outreach tasks and meeting organization.

\section{Call for Contributions:}

The next issue of PAGES News will compare Rates of Change in various aspects of the Earth system as reconstructed in Paleostudies with those measured in the present day. Andre
Paul form Bremen (Germany) will coordinate this issue. André was a visiting scientist at the IPO from July to September 2002. Science highlights that fit within this theme, as well as the usual workshop reports and program news, are welcome. If you are interested in contributing, contact André Paul for science highlights (apau@geo.palmod.unibremen.de) and Christoph Kull (kull@pages.unibe.ch) for all other matters.

All submissions should follow the instructions for authors on our web-site (www.pages.unibe.ch) products/newsletters.html) and be submitted by February 15, 2003. 


\section{LAMSCAN: Detecting rapid environmental changes through studies of annually laminated lake sediments in northern Scandinavia: linkages to the North Atlantic Ocean}

IAN SNOWBall

Lund University, Sweden; Ian.Snowball@geol.lu.se

The LAMSCAN network was founded in 1999 in order to detect rapid environmental change through studies of annually laminated lake sediments in northern Scandinavia, and was coordinated by Ian Snowball of Lund University, Sweden. LAMSCAN is one of four paleo-perspective projects that comprise a multidisciplinary Nordic Arctic Research Programme (NARP) called "Rapid Changes in the Arctic." The aim of all four NARP projects is to study natural archives of climate and environmental change. Supported by a budget of 588,000 Danish Crowns ( $80^{\prime} 000$ \$) over a period of four years, LAMSCAN funds workshops, pilot-fieldwork studies, and PhD student exchanges.

By integrating terrestrial geologists, ecologists and palaeoceanographers, LAMSCAN focuses on the identification of causal linkages between the condition of the high latitude North Atlantic Ocean and the response of ecosystems, as recorded by high resolution sediment records on the land and in the sea. Special attention is paid to the development of varved lake sediment studies in Fennoscandia, such as the potential to provide continuous records of solid winter precipitation over the last c. 10,000 years, decadal scale changes in pollen/macrofossil composition and similar highresolution records of geomagnetic field direction and intensity. As the project developed it became clear that the identification of widely dispersed Icelandic tephra shards in varved lake sediments in Sweden was a crucial building block: not only were the varve chronologies of local applicability, but they could also be used to synchronize geological archives in the North Atlantic region and assign calendar years ages to the

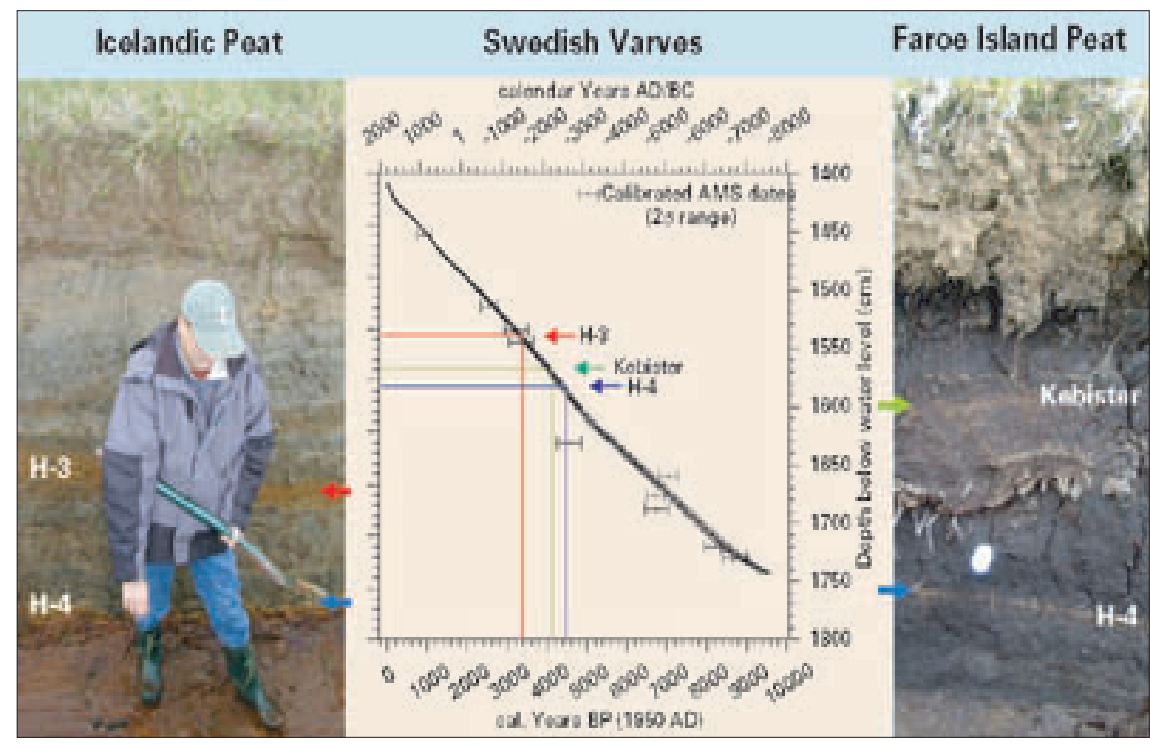

Fig. 1: Tracing, identifying and dating of Holocene tephra layers originating from the Hekla volcano in Iceland. Evidence of the Hekla volcano's explosive eruptions during the Holocene can be traced from Iceland to Fennoscandia (via the British Isles and northern Germany). Through geochemical identification and varve counting it was possible to suggest refined ages of three widely distributed Hekla tephra layers ( $\mathrm{H}-3$, Kebister and $\mathrm{H}-4)$, which can be used to synchronize terrestrial, marine and (hopefully) ice-core records of climate and environmental change (Zillén et al. 2002).

pre-historical tephra isochrons that form the central concept of tephrochronology (Fig. 1).

A recurrent theme has been the accuracy and precision of dating techniques, even for records spaning the last 2000 years, which has become a period of increased international attention. At the various workshops individual researchers often promoted the "high temporal resolution" of their specific proxy records, such as reconstructed sea surface temperatures in the northern North Atlantic, accumulated winter precipitation in Fennoscandia, or the rapid impact of climate change and human disturbance on Faroe Island ecosystems. However, the geo-chronometers currently at our disposal do not allow us to synchronize potential decadal-scale reconstructions of pre-historical ocean-atmosphere interactions in the North Atlantic (such as the North Atlantic Oscillation) to their terrestrial counterparts. When this high-resolution synchronization is achieved our understanding of climate dynamics and environmental change in the high latitudes will take a large leap forward.

Information about the NARP networks can be found at: http://www.thule.oulu.fi/narp/

\section{REFERENCES}

Snowball, I.F., Zillén, L and Gaillard, M-J., 2002: Rapid early Holocene environmental changes in northern Sweden based on studies of two varved lake sediment sequences. The Holocene, 12, 7-16.

Zillén, L.M., Wastegård, S. and Snowball, I.F. 2002: Calendar year ages of three mid-Holocene tephra layers identified in varved lake sediments in west central Sweden. Quaternary Science Reviews, 21, 1583-1591. 


\section{USA Paleoclimate Research Programs \& Role in PAGES}

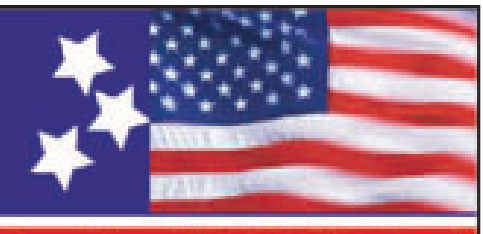

The PAGES Intemational Program Oflice and its activities are supported by national commitments from the United States and Switzerland. The U.S. National Science Fotmdation (NSF) and U.S. National Oeeanic \& Atmospheric Administration (NOA.A) are the primary federal agencies funding U.S. investigators in paleoclimate science as a partnership within the U.S. Global Change Research Program. Smaller paleoseience programs do exist in other agencies, such as the Department of Energy, the U.S. Geological Survey and NASA.

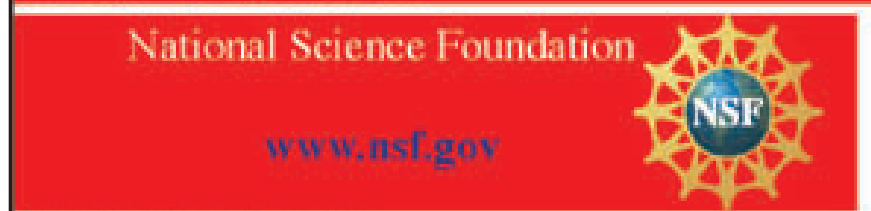

\section{Paleoclimate Programs:}

www,geo.nsf. govicgi-bin'showprog.pl Fid=26\&div=atm

Supports research on the natural evolution of Earth's climate.

\section{Earth System History Annual Competition:}

www.nsf gov/geo/egch/ge_esh_html

Focuses on elements of the coupled atmospherebiosphere-cryosphere-hydrosphere and terrestrial system critical to understanding changing climate over geologic time.

Areas of Interest:

- Holocene climate variability, forcing mechanisms and impacts

- Modes of arctic variability and wamth - Rapid climate change

- Regional patterns / phasing of climate change

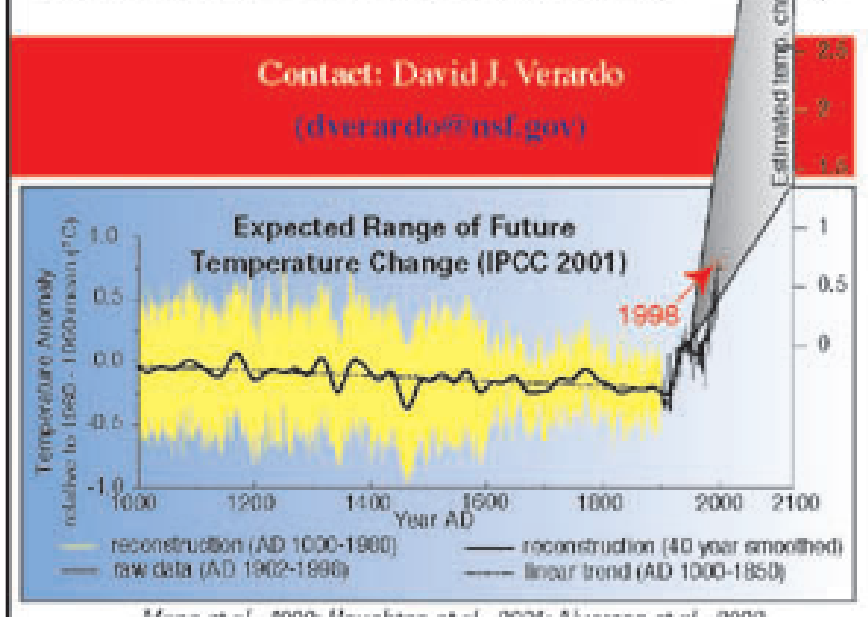

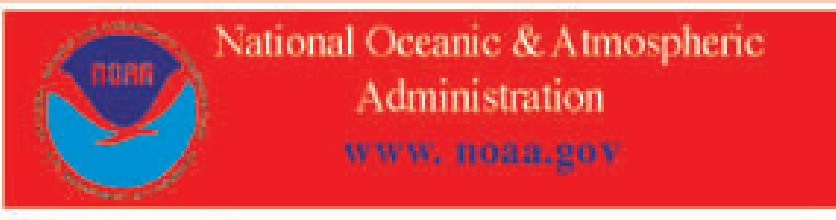

Paleoclimate Program:

www ogp nota govinipe/paleolindex.htm

Focuses on the reconstruction of climate change of the last two tousand years.

Areas of Interest:

- Modes of variability in the past vs contemporary climate

- Onset, frequency, duration, intensity, and spatial heterogeneity of extreme events (e.g. droughts)

- Support for and use of existing data archives at the World Data Center for Paleoclimatology in Boulder, Colorado (www.ngde noas.gow/palea'paleo,html)

Detection and Attribution Program

www.ogpnoaa gowiaboutogp'spotight/detectidatect6_00_htm

Focuses on identifying variability and trends in the climate system and ascribing these changes to causative factors, whether natural or man-induced.

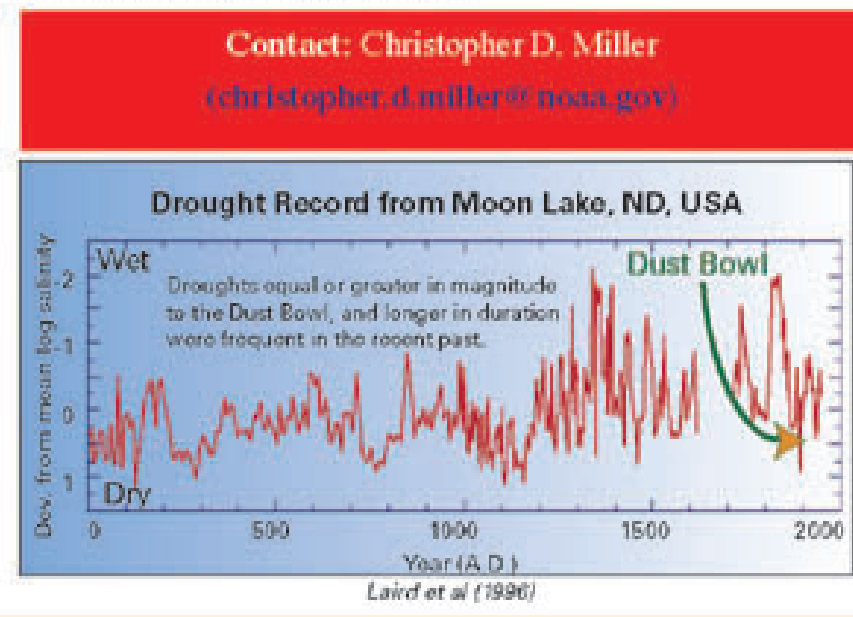

-3rd Int. Limnogeol. Cong, Tucson, Ariwona, Mareh 29 - April 2, 2003

-EGS-AGU-ELiG. Joint Assembly, Nice, France, $06-11$ April 2003

-XVIth INQUA Congress, Reno, Nevada, Juby 23 - July 31,2003

\section{MESH (Manine aspects of Earth System History) SSC - call for four new members}

The committee is comprised of 12 paleoclimatology and paleoceunography researchers, each of whom serves for 3 years. The MESH

Stecring Committee provides scientific input to the Program Dircetors who oversee the ESH Program of the NSF. Further Information: William Cuny (wcurny@whoi.edu) 


\title{
Reconstructing Past Climate and Natural Disasters in Europe Using Documentary Evidence
}

\author{
Christian Pfister ${ }^{1}$, Rudolf Brázdil ${ }^{2}$, Mariano Barriendos ${ }^{3}$ \\ ${ }^{1}$ National Center of Competence in Research on Climate (NCCR), Institute of History, University of Bern, Switzerland; pfister@hist.unibe.ch \\ 2Department of Geography, Masaryk University, Brno, The Czech Republic; brazdil@sci.muni.cz \\ ${ }^{3}$ GAMA Group, Department of Astronomy and Meteorology, University of Barcelona, Spain; barriendos@eresmas.net
}

\section{Historical climatology}

Extending continuous, semi-quantitative monthly and seasonal temperature and precipitation data back into the pre-instrumental period on the basis of documentary data is the primary aim of historical climatology. This branch of science, situated at the interface between climatology and history, has developed methods for interpreting and quantifying documentary data on weather and climate. An additional focus includes the interpretation of current natural disasters within an historical context. Historical climatology also includes investigations into the vulnerability of past economies and societies and explores past discourses on, and social representations of, climate.

\section{Documentary weather and climate data}

A climate historical source is a unit of evidence that contains one of several types of documentary data on weather and climate.

Documentary data are classified according to several criteria (see Table 1)

Direct observations: Documentary data are the only kind of palaeoclimatic data that provide direct observations of meteorological parameters. Most importantly they provide the only evidence that directly relates to socio-economic

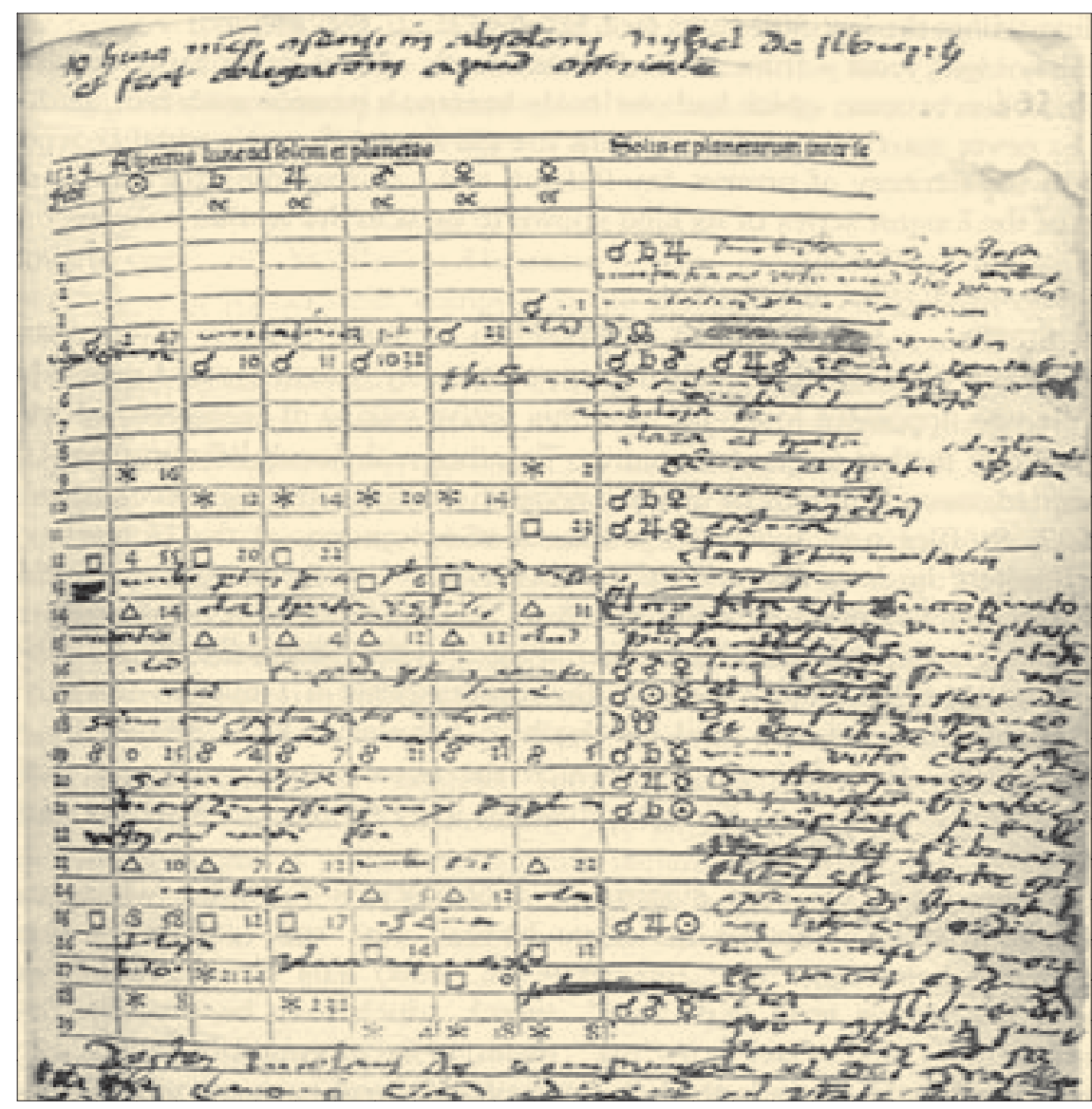

Fig. 1: A page of the weather diary kept by the theologian Marcin Biem at the Jagiellonian University of Cracow (Poland), February 1524. Professor Biem wrote in Latin and he frequently used abbreviations. Entries in weather diaries lend themselves to various forms of frequency analysis. For synoptic analyses it has become commonplace to arrange the entries in tables and represent them using the appropriate symbols of the WMO. climate impacts, in particular with regard to rare but socio-economically significant disasters prior to the period of instrumental measurement. Direct observations may
Table 1: A classification of documentary evidence (adapted from Pfister et al., 1999)

\begin{tabular}{|c|c|c|}
\hline Perception of Weather & \multicolumn{2}{|c|}{ Kind of Evidence } \\
\hline Direct & $\begin{array}{l}\text { Observed } \\
\text { Weather anomalies } \\
\text { Natural hazards } \\
\text { Weather spells } \\
\text { Daily weather } \\
\text { Pictorial }\end{array}$ & $\begin{array}{l}\text { Measured } \\
\text { Barometric pressure } \\
\text { Temperature } \\
\text { Precipitation } \\
\text { Water-gauge etc. }\end{array}$ \\
\hline Indirect (Proxy Data) & $\begin{array}{l}\text { Organic } \\
\text { Phenology } \\
\text { Crop yields } \\
\text { Time of crop harvests } \\
\text { Cultural } \\
\text { Rogation ceremonies }\end{array}$ & $\begin{array}{l}\text { Inorganic } \\
\text { Water levels } \\
\text { Duration of snow, frost and ice } \\
\text { Epigraphical } \\
\text { archaeological remains }\end{array}$ \\
\hline
\end{tabular}

cover all months and seasons of the year. Depending on the type of data (Fig.1), they may have a time resolution ranging from hours to seasons. An example taken from the earliest known weather diary kept on the European continent, dated 1399, reads: "Sept 1 st: day rainy and cloudy, night cloudy and air cold". The author, identity unknown, lived in the surroundings of Basel, Switzerland (Thorndike L., 1966: A daily weather record from the years 1399 to 1406, ISIS 57, 90-91).

Indirect or proxy observations: Many observers were themselves well aware that their narratives included a subjective bias. Thus, they referred to physical and biological 


\section{Science Highlights}

proxy indicators that were known to be more objective yardsticks and that could be compared over time. The group of proxy data is made up of a broad variety of indicators that are as different among themselves as those obtained from natural archives. Each data type needs to be presented for itself in the same way as is done with natural proxy data. An example: "The summer of this year [1347] was so cold and rainy that all crops were extremely slow in growth. All of them had to be harvested unripe" (Chronicle of Zwettl, Austria). Indeed, a long series of tree-ring density data from Lauenen (Switzerland) independently confirms that this particular summer was the coldest of the last millennium.

\section{Continuous and discontinuous observations \\ Discontinuous observations:}

Narrative and/or instrumental observations that were made by individuals for their own sake are discontinuous. Chroniclers often tried to obtain more continuity by copying the observations of their predecessors. Individual perceptions of the environmental are known to be affected by their cultural, social, professional and personal background. For example, professionals, such as wine-growers or farmers, perceive weather in the way it affects their daily affairs whereas intellectuals such as clergymen, early scientists and "amateurs" made systematic attempts to unravel the working of climate in order to derive reliable weather predictions.

Continuous observations: Continuous indirect data are the product of routine administrative processes. They were recorded for socio-economic reasons in an institutional framework. For example, the beginning of wine and grain harvest was regulated by many communities in order to prevent tax evasion. Another example is the regular record of wages paid on Saturdays for community work (e.g. cutting ice at the mills, harvest work) in the town of Louny (NW Bohemia). These were scrupulously recorded in a book of

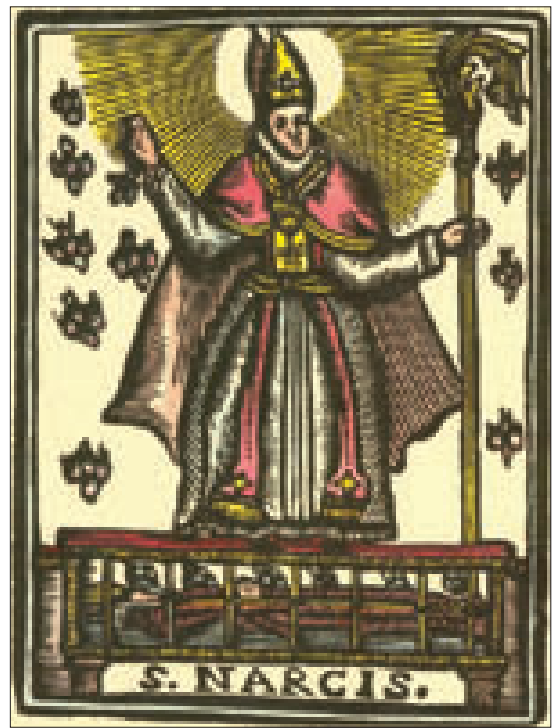

Fig. 2: Saint Narcisus was the first bishop of Girona (NE Spain). His relics were displayed in rogations both for rain and during long periods of rain - for warm weather in summer.

accounts from1450-1632 and can be used as proxies for temperature reconstruction (Brázdil and Kotyza 2000).

Rogations are standardized liturgical actions meant to cope with situations resulting from climatic stress. In the Spanish world they were called forth by guilds and municipal authorities when crops were jeopardized. According to the nature and severity of the climatic stress a specific religious action, such as a prayer at church, the exhibition of relics, a procession or pilgrimage to a shrine was mandated (Fig. 2). The rules for rogation ceremonies were set by the pope. Their costs are laid down both in the accountbooks of the municipalities, as payments, and in those of the church as receipts (Barriendos, 1997).

\section{Spatio-temporal distribution of documentary data in Europe}

The oldest reports on climate anomalies and natural disasters are contained in chronicles from the eighth century AD. Most of these were written in the nascent reign of Charlemagne which included contemporary Germany and France, the Benelux countries, Switzerland and Northern Italy. Some were also written in Ireland and England. From about 1050 the tradition of keeping chronicles spread to the territories of contemporary Catalo- nia, Czech Republic, Denmark, Hungary, Iceland, Poland and Slovakia and somewhat later to the Baltic, Russia and Finland. Records from south-eastern Europe are scanty until the eighteenth century.

The characteristic nature of reports from Western and Central Europe, including Northern Italy, are listeted below.

- Prior to 1300: Reports of socioeconomically significant anomalies and natural disasters.

- 1300 to 1500: More or less continuous reports on the characteristics of summers and winters (to some extent also on those of spring and autumn) including reference to "normal" conditions.

- 1500 to 1800: Almost complete description of monthly weather patterns, to some extent also of daily weather and a growing number and diversity of continuous proxy records related to the rise early local, regional and state bureaucracies.

- 1680 to 1860: Instrumental measurements made by isolated individuals and the first short-lived international network observations (Breslau-Network 1717-1726 and Palatina-Network 1780-1792).

- 1860 onwards: Instrumental observations in the framework of national and international networks.

The list needs to be understood in a cumulative way. Older climate observations are not replaced by, but rather superposed on, more recent ones. In sum, over time the quality of the data improves and their density, spatial coverage and time resolution increase.

\section{Methods for reconstructing temperature and precipitation}

The usual method for reconstructing climate from documentary evidence involves the following steps:

\section{(i) Critical review of sources and} calibration of indirect data

Documentary evidence needs to be critically reviewed according to the rules of historical source interpretation. In particular it must be determined whether the author of the document really witnessed the events he describes or whether 


\section{Science Highlights}
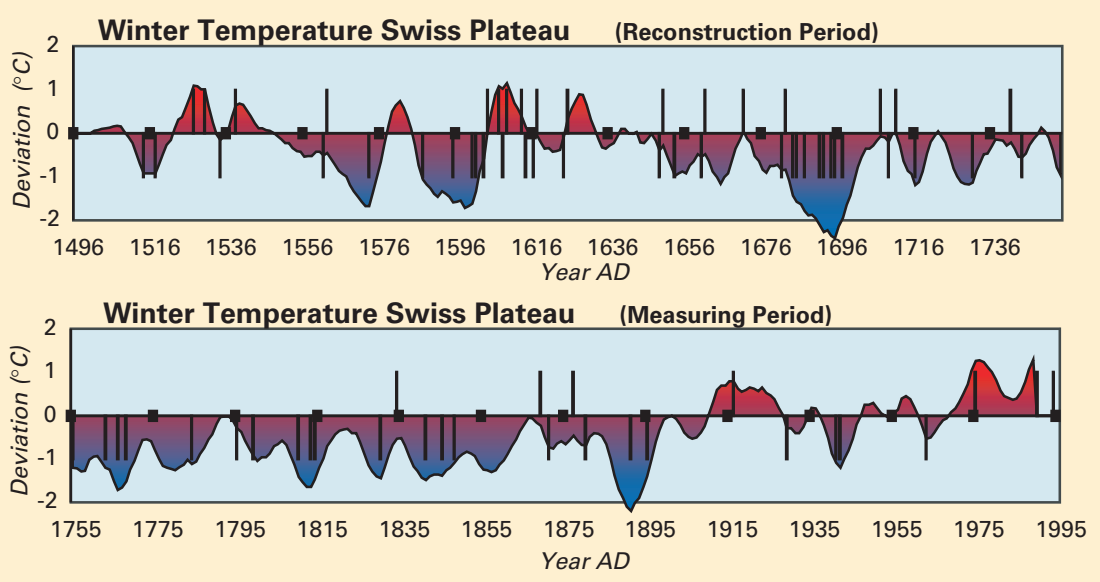

Fig. 3: 11 year running average winter (DJF) temperature in Switzerland 1496-1995. The data for 1496 to 1754 are estimated from documentary evidence. The standard error is $\pm 0.2^{\circ} \mathrm{C}$ The data from 1755 are based on the instrumental series from Basel (Pfister 1999).

he copied the observations from another source. Copying is a major source of misdating. An unreflected use of non-contemporary observations may lead to spurious duplication of extreme events. Reports of climate-dependent physical or biological processes such as the freezing of bodies of water or the times of flowering of plants need to be calibrated against series of instrumental measurements.

(ii) Construction of temperature and precipitation indices

The construction of indices for the pre-instrumental period requires cross-checking all types of data available for a specific month to ensure an unequivocal climatic reconstruction. This involves methodological, source-dependent and interpretative assessments. The result is expressed in terms of an ordinal intensity index for temperature and precipitation, which may include either three or seven classes, according to the time resolution of the evidence. Unweighted index values are: -1 for unmistakably cold or dry months, 0 for "average" months, +1 for unmistakably warm or wet months, whereas the weighted index allows seven classes to be distinguished: +3 extremely warm or wet, +2 very warm or wet, +1 warm or wet, 0 normal, -1 cold or dry, -2 very cold or dry, -3 extremely cold or dry. Seasonal or annual indices are obtained by averaging monthly values which involves calibration and verification.

\section{(iii) Calibration}

Calibration establishes a transfer function between a series of index values and a corresponding series of instrumental temperature or precipitation measurements. During the calibration period both the proxy and measured values must be available.

\section{(iii) Verification}

The relationship obtained by calibration is applied to an independent verification period, for which the values of temperature and precipitation are obtained from the transfer function. These are then compared with the measured values. Various statistical techniques may be used to compare the measured and reconstructed values. It is also necessary to indicate what portion of the variability of the instrumental series is captured by the proxy.

\section{(iv) Assessment of temperature and precipitation}

If the response function obtained captures the variability of temperatures and precipitation with satisfactory precision, the chronology of the index values can be used to provide a reconstruction. As with all proxy records, this procedure assumes that the response function is constant over the entire period of the reconstruction.

This approach has been applied to produce temperature and precipitation reconstructions over the past millennium in Germany,
Switzerland (Fig. 3) and the Czech Republic as well as for deriving a Central European series for the sixteenth century (Pfister et al. 1999).

An alternative method of climate reconstruction using several series of indices for spatial reconstruction of climate parameters is described in the article of Luterbacher et al. (this volume).

\section{Conclusion}

Documentary evidence includes a broad variety of data types, which allow high resolution reconstruction of weather and climate in Europe over the last millennium. These data cover all seasons and months of the year and allow us to distinguish between temperature and precipitation. Significantly, documentary evidence is the only kind available that can lead to the analysis of natural disasters (e.g. severe floods, windstorms, frosts, hailstorms) and their impact upon past societies. The more extreme an event, the more numerous and detailed are its descriptions in historical sources. Thus, analysis of documentary data enables an investigation of the relationship between variations in climate and the frequency and severity of extreme events - a major source of societal concern in light of global warming.

\section{References}

Barriendos, M., 1997: Climatic variations in the Iberian Peninsula during the Late Maunder Minimum (AD 1675-1715): An analysis of data from rogation ceremonies, in: The Holocene 7, 105-111.

Brázdil, R. and Kotyza, 0., 2000: History of Weather and Climate in the Czech Lands IV: Utilisation of economic sources for the study of climate fluctuation in the Louny region in the fifteenthseventeenth centuries. Masaryk University, Brno, $350 \mathrm{pp}$.

Glaser, R., 2001: Klimageschichte in Mitteleuropa seit dem Jahr 1000, Darmstadt.

Pfister, C., Brázdil, R. and Glaser, R.(Eds),1999: Climatic variability in sixteenth century Europe and its social dimension, Dordrecht (Kluwer).

Pfister, C., 1999: Wetternachhersage. 500 Jahre Klimavariationen und Naturkatastrophen (14961995). Verlag Paul Haupt, Bern, Stuttgart, Wien, $304 \mathrm{pp}$.

For full references please consult:

www.pages-igbp.org/products/newsletters/ref2002_3.html 


\section{The LOTRED Approach - A First Step Towards a "Paleoreanalysis" for Europe}

Heinz WANNER AND JÜrg LUTERbacher

Institute of Geography and NCCR Climate, CH-3012 Bern, Switzerland; Heinz.Wanner@giub.unibe.ch, Juerg.Luterbacher@giub.unibe.ch

Temperature is the classical state variable, which is closest to the energy state of the climate system. Therefore, a large number of paleoclimate studies compare either single time series or spatiotemporal reconstructions of surface air temperature with relevant forcing factors (e.g. Mann et al. 1998). In order to analyze and understand the dynamical processes responsible for interannual to centennial scale climate variability over particular regions however, additional important state variables such as air pressure, wind, precipitation and sea surface temperature (SST) must be considered and separately reconstructed. The basic idea of the Long Term REconstruction and Diagnostics (LOTRED) approach is to combine long-term data sets in order to provide a "paleoreanalysis," which allows the diagnosis of important processes. LOTRED also aims to relate trends and variations in atmospheric circulation over the last centuries to European surface climate (temperature and precipitation) variability, and its extremes, as well as North Atlantic sea surface temperature patterns.

\section{Statistical reconstructions of large scale climate fields}

The LOTRED approach is based on the assumption that the four basic state variables, sea level pressure (SLP), temperature, precipitation and SST, can be reliably and independently (no common predictor data for each variable) reconstructed with a sufficient spatial $\left(0.5^{\circ}\right.$ - $5^{\circ}$ ) and temporal (seasonal to monthly) resolution. In Europe, thanks to a large number of long instrumental climate observations, much documentary evidence, and information from natural archives, a detailed study of climate evolution over the last few centuries is possible. Climate information from these different sources, with their complementary strengths, are used

Table 1: Time-series (predictors) available for the European precipitation, temperature, SLP and Atlantic SST reconstructions for winter 1739/1740. (I) stands for indexed data (estimated from high resolution documentary evidence), the remaining series are based on instrumental measurements: Note that the indexed temperature and rainfall indices mostly represent the climatic conditions over a broader geographical area and do not refer to a single station. For more details and sources see Luterbacher et al. (2002).

\begin{tabular}{|llll|}
\hline Precipitation & Temperature & SLP & Atlantic SSTs \\
\hline Podehole (UK) & Central England (CET) & Uppsala (Sweden) & 69 Tree-rings \\
Hoofdoorp (NL) & De Bilt (NL) & Padova (Italy) & series from \\
Kew (UK) & Berlin (Germany) & Northe \\
Zürich (CH) & Uppsala (Sweden) & America, \\
Southern Jordan & Tornio (Finland) & Europa and \\
(Tree ring based) & (I) Swiss Middleland (CH) & \\
(I) Swiss Middleland (CH) & (I) Southern Germany (D) & \\
(I) Southern Germany (D) & (I) Hungary & \\
(I) Hungary & (I) Czech Republic & \\
(I) Seville (Spain) & (I) Western Baltic Sea-Ice & \\
(I) Murcia (Spain) & & & \\
(I) Barcelona (Spain) & & & \\
\hline
\end{tabular}

to estimate large-scale climate variability over the last few centuries. One common method uses a multivariate calibration of the available data against instrumental records. A given large-scale climate variable is calibrated simultaneously against all information in the predictor network. Thus, local relationships between instrumental station time series, documentary and natural proxies and the predictor field are not necessary. The statistical relationship (commonly determined through a principal component-multivariate regression) is usually developed over a calibration period within the 20th century and verified using independent, instrumental observations or through cross-validation exercises. This is done in order to gain insight into how well the derived statistical relations, based on the numbers of predictors during the calibration period, can estimate the climate state of a variable in another independent period. The quality of the reconstructions within the $20^{\text {th }}$ century is usually assessed by a number of statistical measures. To obtain the most reliable recent variability, it is customary practice to use all available data from the $20^{\text {th }}$ century to establishing transfer functions used to derive the reconstructions.

\section{The Extreme Winter 1739/40:}

\section{An Example of LOTRED}

To demonstrate the LOTRED approach, we selected the exceptionally cold European winter of $1739 / 1740$. This example illustrates both the potential and the limitations of independently reconstructing highly resolved temperature, precipitation, pressure and SST fields, based on a combination of a few early instrumental, natural and documentary proxy time series. Table 1 shows the available time series, which were used for the independent reconstructions of the winter 1740 climate fields. For land temperature and precipitation, we used the New et al. (2000) data $\left(0.5^{\circ} \times 0.5^{\circ}\right.$ resolution) for calibration. In the case of the SLP field, we employed data from Trenberth and Paolino (1980) $\left(5^{\circ} \times 5^{\circ}\right.$ resolution). For the Atlantic SST, data were obtained from the analyzed global sea surface temperature (SST) anomalies (Kaplan et al., 1998) $\left(5^{\circ} \times 5^{\circ}\right.$ resolution). Temperature, precipitation and SLP were calibrated with the available predictor sets (Table 1) over the period 1931-1995, and SSTs were fitted over 1856-1940.

\section{Quality assessment of the reconstructions}

The skill of each of the statistical models was assessed over 1901- 


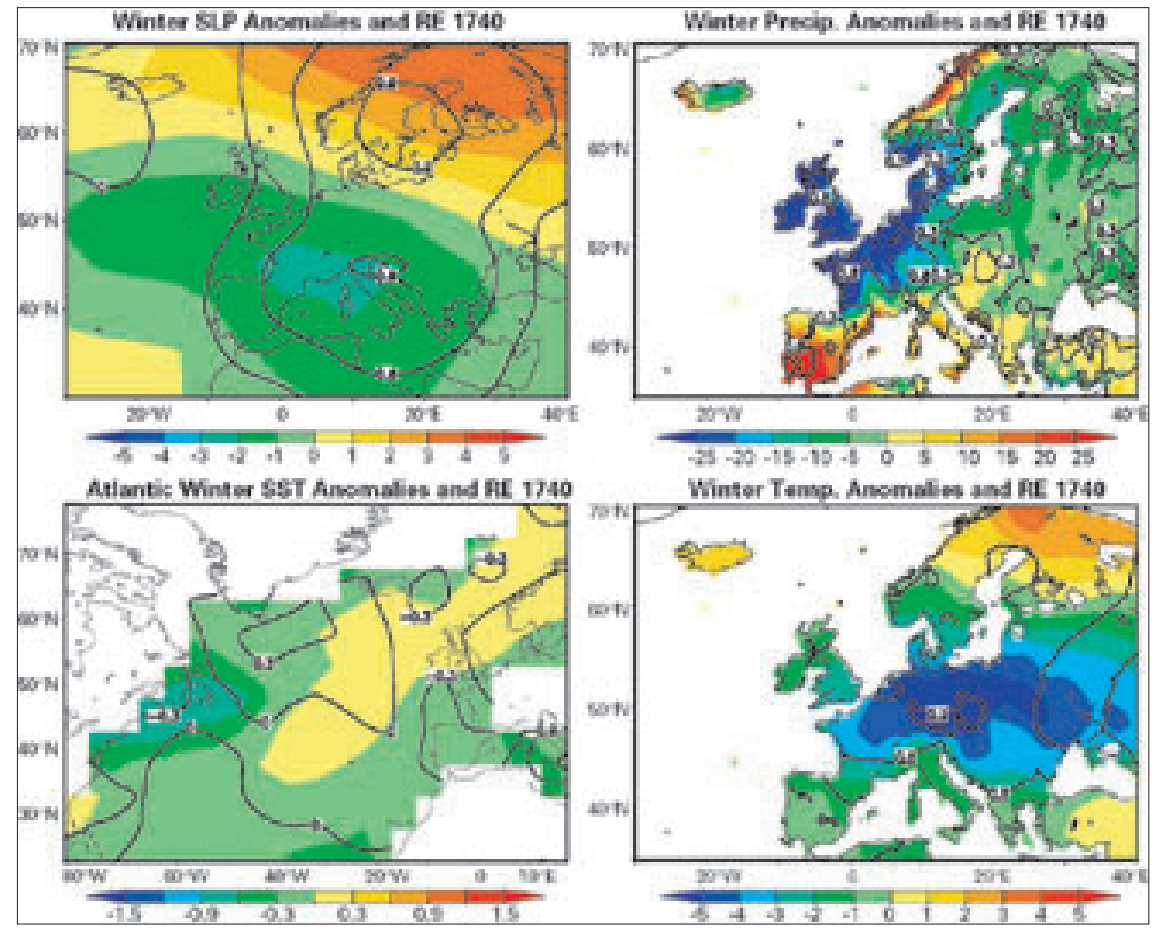

Fig. 1: Reconstructed anomaly patterns for winter (DJF) 1739/40, SLP (top left), European land precipitation (top right), European land temperature (bottom right) and North Atlantic SSTs (bottom left). All fields are plotted with reference to the winter average from 1951-1980. The anomalies for temperature and SST are in ${ }^{\circ} \mathrm{C}$, for precipitation in $\mathrm{mm}$ and for $\mathrm{SP}$ in $\mathrm{hPa}$. Due to the spatial resolution of the SST data, coloured parts of the continent should be neglected. The contour lines in each plot represent the model performance (Reduction of Error, RE) for the reconstructed fields plotted against the time period for which the given statistical model (verification period 1901-1930 for SLP, temperature and precipitation, respectively and 1941-1980 in the case of the SSTs) was used. Areas with $R E>0$ are indicated by solid lines, areas with $R E<0$ are indicated by dashed lines.

1930 (temperature, precipitation and SLP) and 1941-1980 for SST by the Reduction of Error (RE) statistic. The range of $R E$ is $(-œ,+1)$ with a zero value representing the skill of climatology and increasingly positive values representing increased regression skill. $A R E$ of +1 indicates a perfect reconstruction, whereas a RE of -1 is a random guess. The contour lines in Figure 1 thus give an indication of how well the climate fields can be reconstructed based on the available predictor data in an independent period. After the assessment, we recalibrated over the period 1901-1995 (temperature, precipitation and SLP) and 1856-1980 (Atlantic SSTs) in order to derive the winter $1739 / 1740$ fields. For a detailed mathematical treatment of the reconstruction method see Luterbacher et al. (2002).

\section{The winter 1739/40: dynamical aspects}

Figure 1 presents the reconstructed anomalies (with regard to the 19511980 reference period) of SLP, precipitation, temperature and Atlantic SSTs together with the RE values. The reconstructed winter SLP (top left) indicates higher pressure north of $60^{\circ} \mathrm{N}$ with a maximum anomaly of $4 \mathrm{hPa}$ over northern Scandinavia. Lower pressure covers the area to the south with the largest departures occuring over southern France and Italy. The model performance presented by the contour lines indicates positive $\mathrm{RE}$ values over the entire grid with maximum values close to the predictor regions (Padova and Uppsala) and a gradual decrease towards the periphery of the grid. Thus despite having only two station pressure series, meaningful SLP reconstructions can be achieved over continental Europe, though this skill does not extend over the Atlantic ocean west of $20^{\circ} \mathrm{W}$.

It is well known that the largescale atmospheric circulation determines, to a large extent, regional precipitation and temperature anomalies. Thus, advective processes are a crucial factor controlling regional climate changes. According to the reconstructed SLP anomaly pattern, one would expect anomalously dry air to be advected from an easterly direction (Russia) towards continental Europe. In fact, the precipitation anomaly chart (Fig. 1, upper right) clearly indicates a gradual reduction in winter precipitation from east to west. The driest regions are found over north-western Europe and the UK. Wetter conditions are prevalent over the Mediterranean areas, especially over the Iberian Peninsula, which would expected due to a negative NAO situation with more cyclones tracking towards the south. However, not all regional details are due to forcing from the large scale, winter season average circulation. For instance, it is not clear why the western part of Scandinavia received above normal precipitation despite strong positive pressure anomalies. A glance at the higher resolution reconstructed monthly winter conditions reveals that the December 1739 and February 1740 flow over this area was, unlike in the seasonal mean recostruction, from a southwesterly direction. Thus, the effect of these two months might be responsible for the above normal seasonal rainfall anomalies. Generally, areas with a strong intra-winter circulation variability might be expected to have divergent average temperature and precipitation patterns which are not easy to interpret. The quality of the precipitation reconstructions based on 11 rainfall time series is lower and mostly does not reach an RE value of 0.7. Areas with RE values lower than 0.3 should be considered with caution.

The anomalous easterly flow indicated by the SLP anomaly chart is consistent with a large area of Europe showing cold winter temperatures (Fig. 1, lower right). Central and eastern Europe especially, experienced a winter with temperatures up to $5^{\circ} \mathrm{C}$ lower than average. Warmer than normal conditions were only prevalent over Iceland, northern Scandinavia and Russia. This might be due to south-westerly flow over these areas in December 1739 and February 1740. In fact, the station Tornio at the border between Sweden and Finland, also used for the reconstruction, clearly indicates milder conditions compared to the 1951-1980 mean. The RE values for large areas are high and reach up to 0.9 . Thus, with only 10 temperature time series were used, there are large areas with meaningful reconstruction 
skill. In addition, independent climate information sources from various areas, which are not included in the reconstructions, are consistent with the reconstructed temperature and precipitation patterns.

As expected, the reconstruction of the Atlantic SSTs, based on remote tree-ring data from America, Europe and Morocco, reveals only small areas with some reconstruction skill (positive RE-values). These results indicate that the reconstructed SSTs should not be over-interpreted and that more accurate predictors for the reconstructions of this variable have to be found.

\section{Conclusions and outlook}

Reconstruction of European climatic variables over the last few centuries is made possible by the specific combination of data from documentary sources, natural archives and early instrumental measurements. Without documentary data, a satisfactory spatial resolution cannot be achieved for periods when instrumental data are lacking. Thus, they provide an important base for the reconstruction of processes responsible for the strong climate fluctuations in Europe during the second half of the Little Ice Age. We took the first step of developing temporally and spatially highly resolved histories for several climate variables in the past. Such histories are required in order to facilitate the search for an unambiguous 'fingerprint' of recent climate response to increasing greenhouse gas emissions. We therefore hope that our preliminary 'paleorenalysis' results, alongside long-term hindcast runs of coupled general circulation models, will provide a better understanding of the underlying processes associated with both natural and anthropogenic climate change. A question that merits further discussion is whether or not it would make sense to start an initiative to produce a more comprehensive paleoreanalysis product based on further European, or even global, multi-proxy data.

\section{ACKNOWLedgements}

The authors wish to thank Rudolf Brázdil and Mariano Barriendos for providing temperature and precipitation indices for the Czech Republic and Spain. The whole ADVICE, IMROVE, WASA and ALOCLIM projects consortium is acknowledged for the use of their homogenised data.
We wish to express our thank also to Ed Cook and Mary Glueck for providing their tree-ring data and Alexey Kaplan for the use of SST data. The gridded temperature and precipitation data has been supplied by the Climate Impacts LINK Project (UK Department of the Environment Contract EPG 1/1/16) on behalf of the Climatic Research Unit, University of East Anglia. Elena Xoplaki is acknowledged for drawing the figure.

\section{REFERENCES}

Kaplan, A., Cane, M., Kushnir, Y., Clement, A., Blumenthal, M. and Rajogopalan, B., 1998: Analyses of global sea surface temperature 1856-1991, Journal Geophysical Research, 103, 18567-18589. Luterbacher, J., Xoplaki, E., Dietrich, D., Rickli, R., Jacobeit, J., Beck, C., Gyalistras, D., Schmutz, C. and Wanner, H., 2002: Reconstruction of Sea Level Pressure fields over the Eastern North Atlantic and Europe back to 1500, Climate Dynamics, 18, 545-561.

Mann, M.E., Bradley, R.S. and Hughes, M.K., 1998 Global-scale temperature patterns and climate forcing over the past six centuries, Nature, 392 779-787.

New, M., Hulme, M. and Jones, P.D., 2000: Representing Twentieth-Century space-time climate variability. Part II: Development of 1901-1996 monthly grids of terrestrial surface climate, Journal of Climate, 13, 2217-2238.

Trenberth, K. and Paolino, D.A., 1980: The Northern Hemisphere sea-level pressure data set: trends, errors and discontinuities, Monthly Weather Review, 108, 855-872

\title{
The Potential of Archival Sources for Reconstructing Climate and Climate-Related Processes in Latin America
}

\author{
S.e. Metcalfe ${ }^{1}$, M.del R. Prieto ${ }^{2}$, G.H. Endfield ${ }^{3}$, S.J. Davies ${ }^{4}$, S.L. 0'Hara ${ }^{2}$ \\ ${ }_{1}^{1}$ Geography, School of Earth, Environmental and Geographical Sciences, University of Edinburgh EH8 9XP, UK; sem@ossian.geo.ed.ac.uk \\ 2Unidad de Historia Ambiental, Instituto Argentino de Nivologia, Glaciologia y Ciencias Ambientales, 5500 Mendoza, Argentina; \\ mrprieto@lab.cricyt.edu.ar, ohara@geography.nottingham.ac.uk \\ 3 School of Geography, University of Nottingham, Nottingham NG7 2RD, UK; Georgina.Endfield@nottingham.ac.uk \\ ${ }^{4}$ Institute of Geography and Earth Science, University of Wales, Aberystwyth SY23 3DB, UK; sjd@aber.ac.uk
}

Following the conquest of Mexico and large portions of Central and South America in the $16^{\text {th }}$ century, the Spanish Colonial administration began compiling documents on population, settlements, landscapes and economic resources. Combined with the collections of judicial documents including law suits and land grants, the various pictographic, ethnohistorical sources dating back to the pre- and early post-Conquest period and the scientific reports and travelogues of visitors, this archival legacy represents an incredibly rich media of documentary information (e.g. Butzer and Butzer, 1997. The climatic information within the various archival and documentary sources can generally be divided into a number of categories. The first includes direct, dated descriptions and accounts of catastrophic, extreme or damaging, and hence noteworthy climate events such as hurricanes, frosts, droughts or floods. The second includes general anecdotal observations of contemporary climatic conditions, such as the early or late arrival of the summer rainy season, unusually dry or wet conditions and the implications this had particularly for agricultural communities. The third comprises indirect evidence, where the reporting of a climate event per se was not the main purpose of the document. This category might include references to harvest gains or losses, crop blights, disputes over changes in availability of and access to water sources and descriptions of the physical impact of climate change on the landscape as recorded in written descriptions, maps, drawings (pinturas) or photographs.

During the Colonial period a vast quantity of documents from the various levels of the Spanish administration, accumulated in local, regional and national Archives. Documents were also preserved in Spain itself in the Archivo de Indias in Seville and other Spanish archives. The single most important archive in Mexico is the Archivo General de la Nación (AGN) in Mexico City, home to by far 


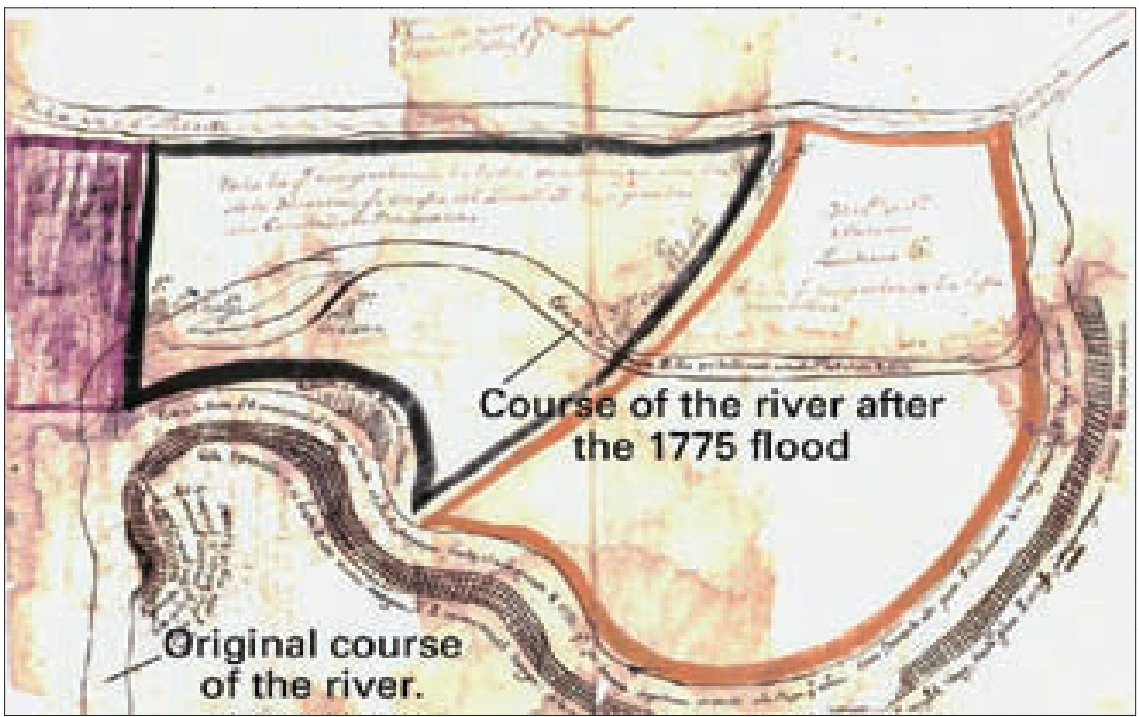

Fig. 1: Map illustrating channel migration of the Rio Atoyac, Oaxaca, Mexico following a flood event in 1775 (Archivo Privado de Don Luis Casteñada Guzman, Oaxaca).

the richest archival collection on the history of the Americas. There are in total 115 ramos (document groups) consisting of over 300,000 individual documents dealing with Colonial New Spain alone now comprehensively indexed on a CD-ROM. The state, regional and municipal level archival repositories, the various archival collections of the different branches of the church and the many private archives across Mexico provide an equally valuable, but under exploited, reserve useful for climate historians. The geographical descriptions (Relaciones Geograficas) of the different regions of Mexico undertaken in the late $16^{\text {th }}$ and late $18^{\text {th }}$ century provide location and period specific information. Other descriptions, accounts and reports such as those provided by travellers, missionaries and scientists who visited the different regions of Mexico also include references to climate characteristics and events.

Among the essential sources for the history of climate in Latin America are the Actas Capitulares which recorded the Cabildo (Mayoralty) activities in the colonial cities on a weekly basis. The climatic phenomena occurring during the week were written down, especially those that had adverse economic consequences, like droughts and floods. Their characteristic is their continuity through time and their homogeneity. The Actas from the cities of Santiago de Chile and Buenos Aires were published in their en- tirety at the end of the $19^{\text {th }}$ century. Potosi has an exceptional collection of Actas extending back to 1585, but they remain unpublished. In Chile and Argentina, southern areas were colonised later than the north, the coastal areas first and later the Andean zones. The scarce information from before the $19^{\text {th }}$ century comes from those coastal cities and from the chronicles written by the priests travelling across the region.

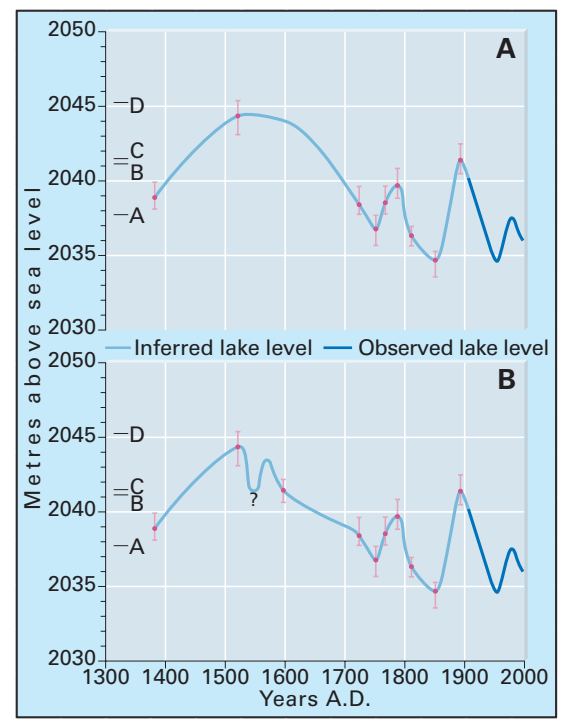

Fig. 2: Changes in the level of Lake Pátzcuaro, Mexico since ca. 1380. A) original figure from O'Hara 1993 (The Geographical Journal, $159,51-62), B)$ revised figure based on more recent archival searches. Letters $A$ to $D$ refer to reference points in the basin: Copujo only exists as an island with lake level between $A$ and $B$. Apupuato becomes an island when the lake stands above $C$, below this level it is connected to the mainland. When lake level rises above D, Tzentzencuaro becomes an island.

\section{Direct meteorological observations}

The first systematic records of climatic variables were made in Mexico in the second half of the $18^{\text {th }}$ century. Most early records are for precipitation only, but regular reports of temperature and precipitation were published in the Mexico City newspaper, El Sol, from 1826. The Central Meteorological Observatory was established in 1877 and a national network of meteorological stations was instigated. The Servicio Meteorologico de Mexico was founded in 1921. The collection of meteorological data was severely disrupted in the period leading up to and during the Mexican revolution (1917). The longest single record comes from the Tacubaya Observatory in Mexico City (started 1884, extended by interpolation to 1877). In Chile and Argentina amateurs systematically recorded temperature, rainfall and other meteorological phenomena in the $19^{\text {th }}$ century, in spite of civil wars and political anarchy. In Mendoza this started in 1823. In the city of La Paz, Bolivia, the most important meteorological records were compiled by the Jesuits, who recorded the weather in San Calixto de La Paz from 1891 until the present day. Meteorological offices began in Argentina and Chile in the last quarter of the $19^{\text {th }}$ century. The province of Buenos Aires was a pioneer, having a meteorological observatory from the middle of the $19^{\text {th }}$ Century. Newspapers began reporting weather phenomena around 1850.

\section{Mexico}

Investigations have highlighted the potential of various ramos in the AGN dealing with crops and harvests as indices of climatic variability. Drought histories have been reconstructed based on crop prices, harvest records (e.g Alhondígas) and newspaper reports (Gazeta de Mexico) and on correspondence between hacienda administrators (Archivo de la Historia de la Hacienda) in the Basin of Mexico (Florescano and Swan, 1995). Extensive archival analyses of litigation documents have highlighted a potential correlation between increased legal 
conflict over the use of and access to water sources and periods of drought (Endfield and O'Hara, 1997). Judicial documents dealing with land grants (Mercedes) and law suits over land and water (Tierras) are among the most useful archival sources for climate historians. Such documents often include descriptions of changes in hydrological regimes or vegetation related to climate.

Historical maps and pinturas have long been used in the reconstruction of regional environmental histories in Mexico, but can also provide useful information on past climatic conditions and the impacts of specific climate events. A map taken from a private archive in Oaxaca, drawn to illustrate changes in property boundaries, shows the impacts of an extreme flood event in 1787 on a river channel (Fig. 1). The form of the river channel before and after the event is illustrated and described with written annotation.

Law suits over submerged tracts of land, coupled with historical maps, postcards, photographs, oral histories and instrumental records have been used to reconstruct fluctuations in lake levels indicative of climate change. Changes in the level of Lake Pátzcuaro in Michoacán were reconstructed by Sarah O'Hara from $1300 \mathrm{AD}$ to the present day (Fig. 2). Additional archival research, primarily using information derived from law suits held in the Archivo de las Notorias, Morelia, Michoacán, (Tierras y Aguas) has helped to refine this lake level curve, with instrumental records covering the period since 1949.

\section{Southern South America}

In southern South America (Cono Sur), the conquest began at almost the same time in the Rio de la Plata area of Argentina (1536-1537) and Perú ( 1532-1535), continuing into Bolivia (1538) and Chile (1545). In South America there is more climatic information for the colonial period $\left(16^{\text {th }}-18^{\text {th }}\right.$ centuries $)$, than for the $19^{\text {th }}$ century. When those cities with archives had been headquarters of the viceroyship, gobernaciones or corregimientos, there can be a huge quantity of climatic information. This

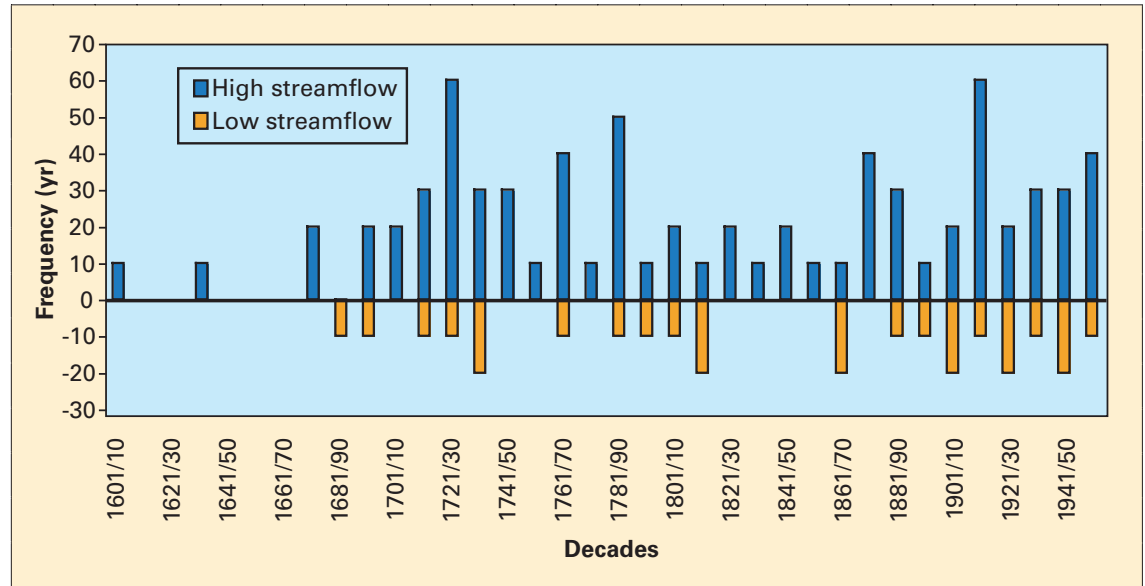

Fig. 3: Reconstructed percentage occurrence of high and low streamflow, by decade, for Mendoza, Argentina for the period 1601 - 1960.

is the case for Buenos Aires, headquarters of the Virreinato del Río de la Plata (1776) or Santiago, headquarters of the Capitanía General de Chile. The Archivo Histórico Nacional de Chile is the most complete in the country. In Argentina, the Archivo General de la Nación contains the largest amount of information. For Bolivia, documents can be found in the Archivo Nacional de Bolivia in Sucre, and in other regional archives such as Oruro and Potosi. There are also collections in monasteries and convents. In Argentinian Patagonia, systematic information starts as late as 1879.

The archives are organized by sections. In the colonial section, the holdings of correspondence are particularly significant. Extreme climatic events affecting the regional economy such as droughts, floods or abundant precipitation, were reported in letters, notes and reports to the Spanish Crown. In other sectors, account books or books on harvests expenditures, instructions about food supplies, compilations of agricultural and cattle prices, can be examined. There are also specific reports on climatic events such as the "Semestral Relations of waters, harvests and other particulars" from the end of the18th century onwards. These provide direct data on climate and agriculture, primarily for Argentina, Bolivia and Paraguay between 1784 and 1810. Annals, chronicles or diaries from priests, religious orders, the military or individuals, complete the range of climatic information.

In Mendoza, Argentina the Actas Capitulares and other sources have been used to reconstruct variations in temperature and precipitation during the $17^{\text {th }}$ and $18^{\text {th }}$ centuries (Prieto et al. 2000) and the Mendoza River streamflow over 350 years (Fig. 3). At Potosí, where mining depended on water resources, dry years were recorded. In Santiago it is possible to find data about floods and heavy rains that devastated the central region of Chile.

The arrival of naturalists, scientists and explorers increased the amount of information for the south of South America. New settlers also made a significant contribution.

\section{Conclusions}

Many different types of information can be used to reconstruct quite detailed records of climatic change over the historical period. Indeed, records derived from crop prices, lake level changes and anecdotal information in the highlands of central Mexico illustrate that annual rainfall in central Mexico has varied considerably over the course of the past 600 years. (O'Hara and Metcalfe, 1995) These data can be integrated with the early instrumental record to provide continuity through to the present day.

The reliability of the data derived from archival sources, however, warrants scrutiny. Unusual weather was, by definition, more noteworthy than normal weather conditions. Historical documents thus tend to be biased towards describing and depicting anomalous and extreme climate events. Archival reconstructions may thus seem to illustrate a society more sensitive and poorly adapted to climatic events than it ac- 
tually was. Moreover, though many of the documents represent the reporting of events and experiences as they took place, they also reflect the positionality, and purpose of the author and the intended audience. Subjectivity and bias will also influence the validity of the information conveyed and used for constructing climatic chronologies. It is difficult to establish from documentary sources, for instance, what constituted normal climatic conditions. There may also be some cases (for example during political upheavals) when unusual climate goes unreported in either the documentary or instrumental record. Whether a climate event is recorded is also dependent on the size of the potentially affected population and its level of economic development.
Climatically-induced agricultural failure, for instance, is only likely to be recorded if a significant number of people are affected by harvest losses. It is also likely that the frequency of singular events might be relatively under recorded in comparison with recognised severe climatic phases, where bad conditions persist over several years.

Such interpretative problems can compromise the value of archival records of climate change. The collections of historical documents available for Latin America as a whole are extremely rich and diverse. Used carefully, these archives can provide us with an invaluable and as yet still under-exploited medium for the reconstruction of detailed regional climate histories.

\title{
ENSO Reconstruction Based on Documentary Data From Ecuador, Peru and Chile
}

\author{
Luc 0rtlieb 1 , Gabriel Vargas ${ }^{2}$ and AnNe-Marie Hocouenghem 3 \\ 1 UR PALEOTROPIOUE, IRD, Bondy (France); Luc.Ortlieb@bondy.ird.fr \\ 2Depto. de Geología, Universidad de Chile \& UR PALEOTROPIQUE, Santiago (Chile); gvargas@ing.uchile.cl \\ ${ }^{3}$ CNRS \& IRD, Institut Français d'Etudes Andines, Lima (Peru); amhocquenghem@terra.com.pe
}

The first chronology of ENSO occurrences in the past centuries was based on documentary data from South America. A review of the sources and a closer look at the geographical distribution of ENSO impacts across the subcontinent revealed that the sequences of $\mathrm{El}$ Niño events previously proposed (Quinn, 1987) should not be used for calibration purposes until a better knowledge of the regional impacts of ENSO is obtained. On-going research on documentary sources from central Chile and Peru suggests that the current teleconnection patterns were different prior to the early $19^{\text {th }}$ century. If correct, this hypothesis may have important consequences for understanding multidecadal and century-scale ENSO dynamics.

\section{Quinn's historical sequence of El Niño events}

The El Niño phenomenon was defined in 1891, in northern Peru, as a combination of anomalously warm sea temperature, stronger than usual southward coastal current and high rainfall in the Sechura desert. In successive works (Quinn et al., 1987;
Quinn \& Neal, 1992; Quinn, 1993), Quinn proposed a chronological sequence of EI Niño events, covering the last $41 / 2$ centuries, with an individual strength evaluation and confidence rating of every episode. In his last reconstructions, Quinn incorporated more data from Chile and Brazil than from Peru. In his last published work (1993), he also considered a series of documentary and hydrological proxies from the western Pacific and Indian ocean regions, and proposed a global ENSO sequence to be compared with his "regional" (= South American) El Niño sequence (see Fig. 1, left column).

Quinn's sequences have been considered the major reference for most studies of variability in ENSO recurrence and intensity throughout the last four and a half centuries. However, a close re-examination of the same documentary data used by Quinn, and/or additional documents, from Peru, showed that serious doubts must be expressed regarding the real occurrence of a number of these reconstructed EI Niño events (Ortlieb, 2000). In some cases, there

\section{REFERENCES}

Butzer, K.W. and Butzer, E.K., 1997: The 'natural' vegetation of the Mexican Bajio: archival documentation of a 16th-century savanna environment. Quaternary International 43/44, 161-172.

Endfield, G.H. and O'Hara, S.L., 1997: Conflicts over water in 'The Little Drought Age' in Central Mexico. Environment and History 3, 255-272.

Florescano, E. and Swan. S., 1995: Breve historia de la sequía en México. Universidad Veracruzana, Xalapa.

O'Hara, S.L. and Metcalfe, S.E., 1995: Reconstructing the climate of Mexico from historical records. The Holocene 5, 485-490.

Prieto, M., R. Herrera and Dussel, P., 2000: Archival evidence for some aspects of historical climate variability in Argentina and Bolivia during the 17th and 18th centuries. In: Southern Hemisphere Paleoand Neoclimates. W. Volkheimer and P. Smolka (eds) Springer-Verlag, Berlin-Heidelberg, $381 \mathrm{p}$.

Quinn, W.H., V.T. Neal and Antúnez de Mayolo., S., 1987: El Niño occurrences over the past four and a half centuries were misinterpretations of written data or problems of unreliability of the sources used by Quinn. In other cases, strong documentary evidence from northern Peru and southern Ecuador contradicts the reconstruction of so-called El Niño events (see below). Additionally, in numerous instances, Quinn interpreted occurrences of El Niño events solely from information on heavy rainfalls in central or southern Peru, or in Bolivia (Potosi), or from a single source. These are areas where precipitation excess cannot be reliably linked to EI Niño conditions even in the modern instrumental period.

\section{Western South America: a key region for ENSO reconstructions}

The Pacific coast of South America is undoubtedly a key area for paleoENSO studies, both because of the availability of written records since 1525 AD and because of the strong impact of the ENSO phenomenon in two specific regions.

Analyses of instrumental data of the $20^{\text {th }}$ century confirm that the positive rainfall anomalies over the coastal regions of Ecuador and northern Peru 


\section{Science Highlights}

show the only statistically significant correlation with EI Niño events within the whole region encompassing Ecuador, Peru and Bolivia (Aceituno, 1988; Rome Gaspaldy and Ronchail, 1998; Ronchail; 1998; Rossel et al., 1998). Assuming that this relationship could be extrapolated into the past, Ortlieb (2000) proposed that positive rainfall anomalies could be used as a major criterion for the reconstruction of former ENSO events. Accordingly, written records on high rainfalls in any given year would support the interpretation of former El Niño conditions, and inversely, reports on drought would be interpreted as normal (or La Niña) conditions. These same criteria are currently being used by Ortlieb and Hocquenghem (in prep.) for an up-dated sequence of El Niño occurrences from Peruvian documentary data (Fig. 1, column 2). For a better assessment of the reconstructed past El Niño events, emphasis is given to the multiplicity of converging reports covering an area extending from Guayaquil to Trujillo (bars in violet in Fig. 1 Column 2).

In central Chile, a well-established correlation links positive (negative) rainfall anomalies and El Niño (La Niña) events (Rutllant and Fuenzalida, 1991). $80 \%$ of the total annual rainfall over Santiago $\left(33^{\circ} \mathrm{S}\right)$ occurs during austral winter. Significant positive winter rainfall anomalies are produced during the development phase of EI Niño events, contemporaneous with the weakening of the Pacific Subtropical Anticyclone (PSA), i.e. negative values of the Southern Oscillation Index (SOI), and with other synoptic anomalies. Inversely, negative rainfall anomalies and severe droughts are well correlated with La Niña events and a strong PSA (Rutllant and Fuenzalida, 1991) (Fig. 2). Thus, the relationship between rainfall anomalies over this region and ENSO seems strong enough to enable reconstructions of past events. The advantage of this region over northern Peru is that La Niña events may be inferred from drought data.

From the point of view of historical climate studies, it is clear that written reports constitute a

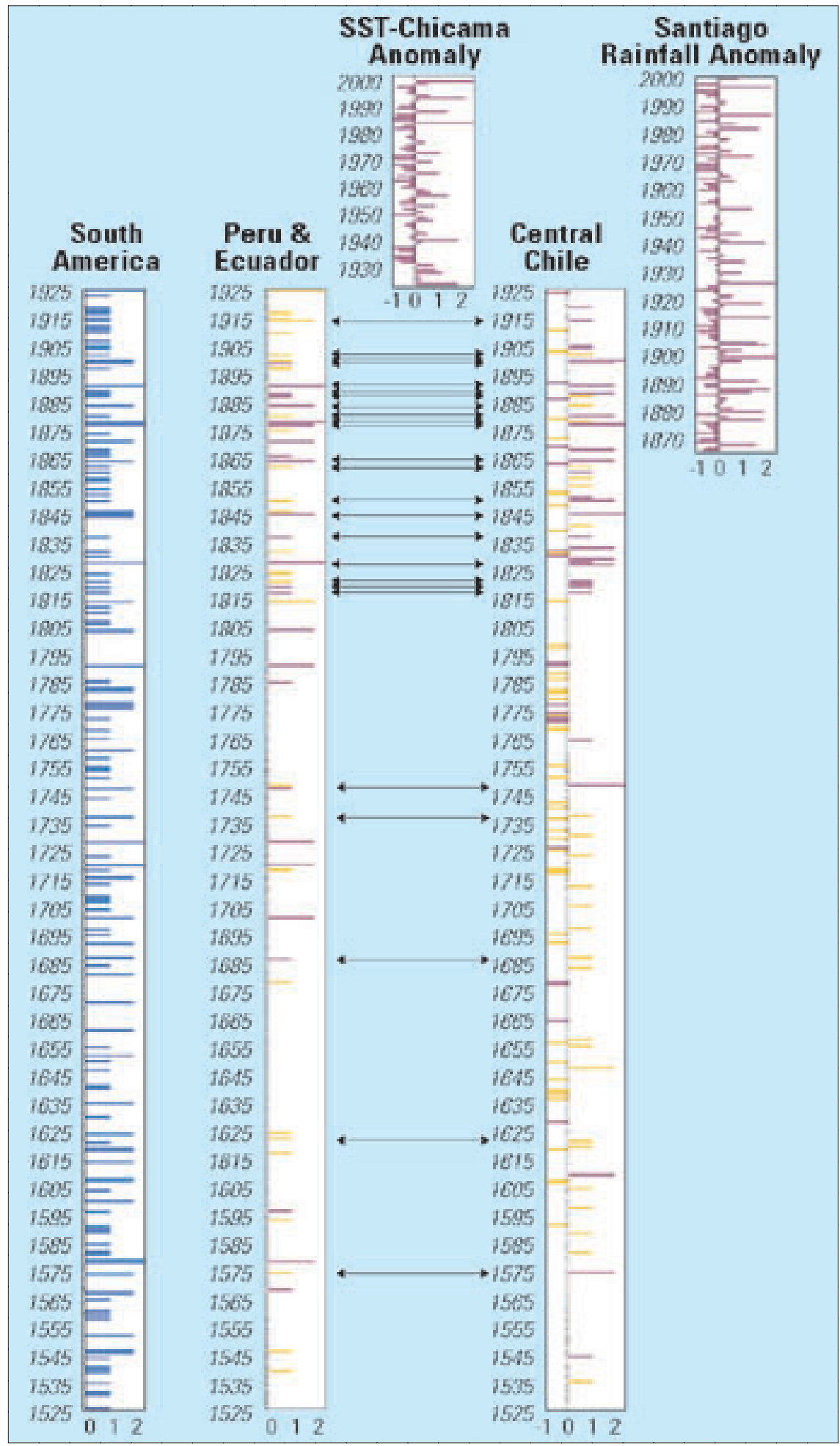

Fig. 1: Comparison between historical sequences of ENSO events, reconstructed from documentary data from the whole of South America (Quinn, 1993), Ecuador/Northern Peru (Ortlieb, 2000; Ortlieb and Hocquenghem, in prep.) and Central Chile (Ortlieb, in prep.). For the historical sequences: -1: La Niña events (only for Central Chile), 0: normal years (or lack of relevant data), 1, 2 and 2.5: weak and moderate, strong, or very strong El Niño events, respectively. Yellow bars correspond to less robust data. Horizontal arrows indicate the coeval El Niño related conditions in Central Chile and Ecuador/Northern Peru. Standardized anomalies of the mean (February-May) SST, at Puerto Chicama (northern Peru) for the period 1925-1998 and annual rainfall at Santiago (central Chile) for the period 1866-2000 both correlate significantly with ENSO.

valuable data base, extending back to the early $16^{\text {th }}$ century. In the arid regions of coastal Peru and southern Ecuador, as in the areas dedicated to agricultural activities (central Chile), the amount of precipitation and the occurrence of river floods were commonly reported or referred to in several kinds of documents. In Santiago, the droughts gave rise to 


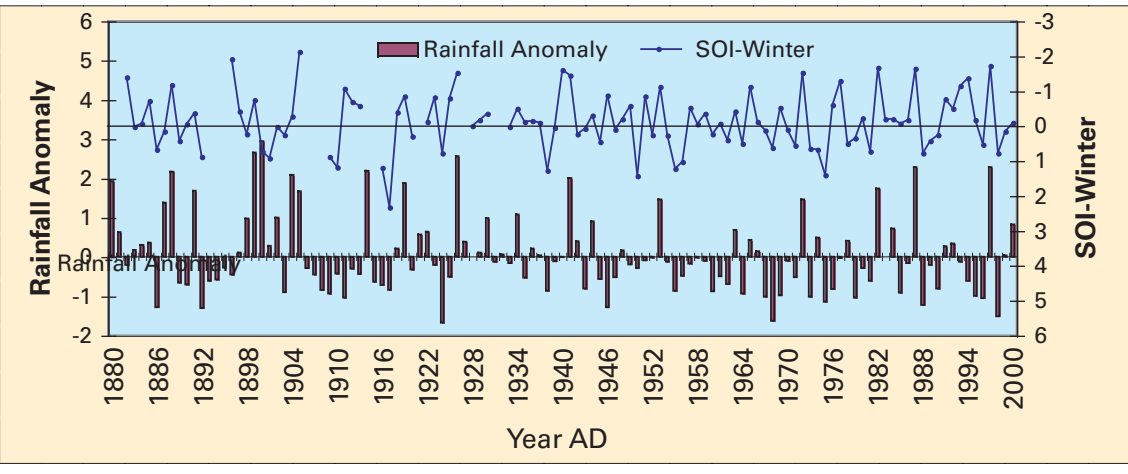

Fig. 2: Comparison between the standardized anomaly of annual rainfall at Santiago and the mean SOI for the austral winter (May to August). The two series are significantly correlated $(r=-0.5, p<0.01)$

"rogativas" (processions organized by the Church to implore the Virgin and the saints to provoke rainfall) that were systematically discussed in the "Cabildo" (town hall) and reported in its official records. Thus, in areas largely influenced by the ENSO system we can fortunately rely upon relevant documentary reports.

\section{From colonial written data to the reconstruction of El Niño events}

In the area of Ecuador under the influence of ENSO conditions (between Manta, Guayaquil and the Peruvian border) documentary records are relatively scarce. In the case of Peru, the key area for the most reliable El Niño impacts (Piura andTrujillo provinces) lies far away from Lima, the center of colonial life, and only discontinuous chronicles and anecdotal data are available. Ironically, the destruction of municipal archives in northern Peru was due to several floods produced during strong El Niño years. Unfortunately, the relatively abundant information on climate anomalies in Lima and on the Rimac River floods are of limited interest because they do not necessarily reflect $\mathrm{EI} N$ iño conditions (Ortlieb, 2000).

In Chile, the longest available chronicle of weather anomalies is that of Santiago ("Actas del Cabildo"). This is most fortunate since this almost uninterrupted documentary database is located in the center of the zone of maximum impact of ENSO conditions. In northern Chile, reports on climate anomalies can also be used for the reconstruction of El Niño (rainfall excess in coastal rainfalls in the Chilean altiplano). The identification of former El Niño in coastal areas of southern Ecuador and northern Peru, and in central Chile, is thus primarily based on written reports of rainfall excess and of associated manifestations (river floods, bridge destruction, agricultural consequences). In some cases additional information, such as reports of warmer air (or sea) temperature, sudden fish mass-mortality, anomalous wind patterns, may also be relevant. The intensity of the catastrophic impacts and their geographical extension help to evaluate the strength of the former events. Because of the general aridity along the coast of Peru and southern Ecuador, it is only from the central Chile record that La Niña events can be reliably reconstructed (Fig. 1, column 4).

Unlike Quinn, we rely only upon reports from independent eyewitnesses (or, at least, first informants), disregarding any secondary (or tertiary) sources.

\section{Comparison of the regional historical El Niño sequences}

Comparison of the three historical sequences shown in Fig. 1 leads to the following conclusions:

- The "South America" sequence includes most of the reconstructed events of columns 2 and 3 (plus a few events inferred from data from Bolivia and Brazil). This "aggregating" approach tends to increase the number of reconstructed former El Niño events and implies the existence of dynamically implausible sub-regional manifestations of ENSO. areas) or La Niña episodes (strong
- The lower number of El Niño events recorded in Ecuador/Peru and central Chile during the $16^{\text {th }}$ to $18^{\text {th }}$ centuries is partly due to differences in the availability and reliability of the documentary data, as compared to the $19^{\text {th }}$ century. However, it is inferred that a real increase in the frequency and intensity of events did occur in the $19^{\text {th }}$ and $20^{\text {th }}$ centuries.

- A good correlation is observed between the documented records of Ecuador/Peru and Chile after 1817. This tendency is confirmed by agreement with instrumental data during the $20^{\text {th }}$ century.

- Prior to 1817 the two records are overwhelmingly discrepant: a very limited number of events were coincidentally reconstructed in the two areas. This lack of correlation between the two series cannot be assigned solely to a lack of information, because in many cases available data in one region points to normal or La Niña conditions, while El Niño manifestations are recorded in the other area. This implies a change in ENSO related teleconnection patterns occurred abruptly around 1817.

- The lack of correlation between the two records is independent of the strength of the reconstructed events. The strongest (and better documented) reconstructed events do not show a better correlation than episodes of minor intensity. This evidence supports the conjecture that the teleconnection pattern observed in the last two centuries was different in earlier times.

\section{Toward a robust sequence of El Niño events}

The consolidation of a single, robust chronological sequence of El Niño occurrences in South America, will involve further investigations in the following directions:

- Development of systematic documentary studies for all the years subject to El Niño conditions in core regions, as well as less well studied regions known to be influenced by the ENSO system. This may include the Nordeste of Brazil, as well as central Chile and southern Ecuador/ northern Peru. 


\section{Science Highlights}

- Intercalibration of documentary records from central Chile and annually resolved dendroclimatic data from both Chile and Argentina.

- Modeling of the dynamics of regional atmospheric circulation pattern that might account for changes in the ENSO teleconnection system at interannual to interdecadal time scales.

\section{REFERENCES}

Aceituno, P., 1988: On the functioning of the Southern Oscillation in the South American sector. Part 1 surface climate. Mon. Wea. Rev., 116: 505-524.

OrtLEB, L., 2000: The documentary historical record of El Niño events in Peru: An update of the Quinn record (sixteenth through nineteenth centuries). In El Niño and the Southern Oscillation: Variability, Global and Regional Impacts, H. Diaz \& V.

Markgraf (Eds.), Cambridge University Press. Cambridge.p. 207-295

QuinN, W.H., 1993: The large-scale ENSO event, the El Niño, and other important features. Bull. Inst. Franç. Et. Andines, 22 (1), pp. 13-34.
Quinn, W. Ne Neal, VT. and Antunez de Mayolo, $S$, 1987: El Niño occurrences over the past four and a half centuries. Journal of Geophysical Research, 93(CI3), pp. 14449-14461.

QuINN, W.H. and NeAL, V.T., 1992: The historical record of El Niño events. In Climate since A.D. 1500. R.S Bradley \& P.D. Jones (eds.), London; Routledge, pp. 623-648.

For full references please consult:

www.pages-igbp.org/products/newsletters/ref2002_3.html

\section{Summer and Winter Temperature Reconstructions in Japan}

\section{TAKeHIKo MiKami}

Department of Geography, Tokyo Metropolitan University, Tokyo 192-0397, Japan; mikami@comp.metro-u.ac.jp

In Japan, a great number of weather diaries from most parts of the country are preserved in local libraries and museums (Fig. 1). Some outstanding official diaries have been kept continuously since the seventeenth century. Over the last few decades, most of the known daily weather records were digitized and added to the Historical Weather Database of Japan (e.g., Mikami 1988 and 1999). Another valuable source for historical climatology in Japan is the freezing date record of Lake Suwa (central Japan). These dates were systematically recorded from the fifteenth century onwards. In this paper, we explain how summer and winter temperatures were estimated, based on a century long weather diary and the half millennial Lake Suwa record.

The reconstruction of summer (JJA) temperatures draws on the monthly number of rainy days in Tokyo from 1721, which were obtained from the "Ishikawa diaries" (Mikami, 1996). Initially, the data

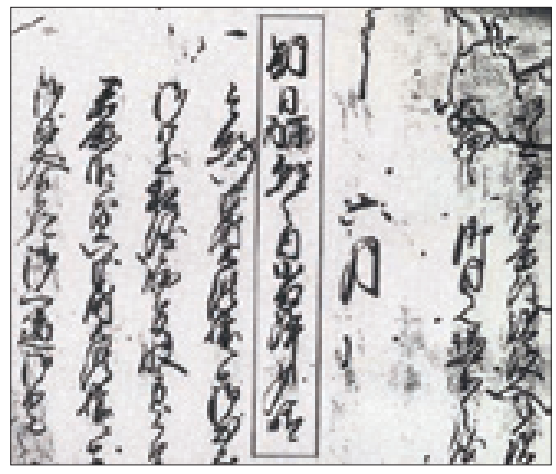

Fig. 1: An example of a weather diary from Japan, $18^{\text {th }}$ century. Daily weather conditions are described in detail. The boxed area says "a little rainfall in the morning, but became fine in the evening."

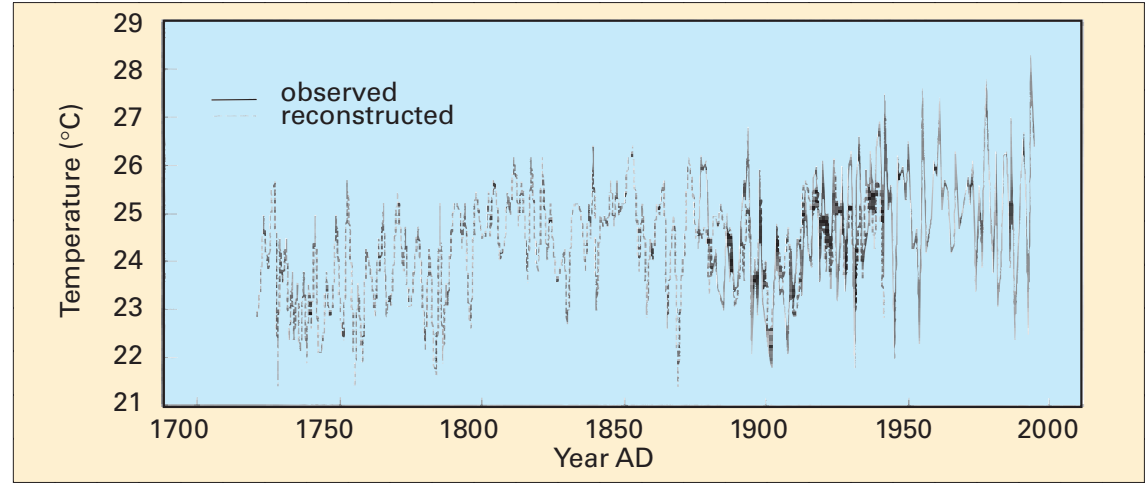

Fig. 2: July temperature variations in Tokyo for 1721-1995.

were calibrated with the long temperature series of Tokyo over the period from 1876 to 1940, using linear regression techniques. It turns out that the correlation between the monthly number of rainy days and mean monthly temperatures was highest for July ( $r=-0.70$, significant at $1 \%$ level). This is related to the prevailing weather situations. Under the influence of a strong subtropical anticyclone, July is hot and dry, whereas stagnant polar fronts and passing extratropical cyclones are associated with cool and rainy weather situations. Consequently, July temperatures were estimated from the recorded number of rainy days for the period 1721 to 1875 , using a regression equation. Finally, the estimated temperatures were used to extend the instrumental series of Tokyo (1876 to 1995) back to 1721 (Fig. 2).

Long temperature trends can be explained using weather diaries, as in Figure 1. From 1721 to 1790 , July temperatures were about 1 to $1.5^{\circ} \mathrm{C}$ lower than the 1961-1990 mean. During this period of cool summers, July temperatures displayed a large year- to-year variability. Cold summers were registered in 1728, 1736, 1738, 1755, 1758, 1783, 1784 and 1786. During the 1780's severe famine occurred repeatedly. On the other hand, many warm summers stand out in the record for the nineteenth century, in particular in the 1810s and from 1851 to 1853. July was again remarkably cool around 1900 . This observation is clearly captured by both estimated and measured temperature series.

The reconstruction of winter temperatures is based on the Lake Suwa record. When the lake froze, shrinkage and expansion of the ice sheet due to diurnal temperature variations caused an ice cracking phenomenon called "Omiwatari," which was said to resemble "a bridge crossing the lake" (Fig. 3). The ancient village people might have believed it to be the track of a god visiting a goddess on the opposite shore. Since the fifteenth century, the formation of "Omiwatari" has been celebrated in a ceremony a couple of days after its occurrence. The dates of "Omiwatari" have been recorded by the Suwa shrine since the $15^{\text {th }}$ century, 
and also by the Suwa meteorological observatory independently since 1951. During a cold winter, "Omiwatari" would already have occurred by mid- December, whereas in a warm winter, it would be delayed until the end of February, or no "Omiwatari" would occur at all.

A linear regression of the freezing dates with the instrumental series of the Suwa meteorological observatory revealed that December-January mean temperatures are highly correlated $(r=0.80$, significant at $1 \%$ level) with the Lake Suwa series over the calibration period 1945-1990. Based upon the regression equation, win-

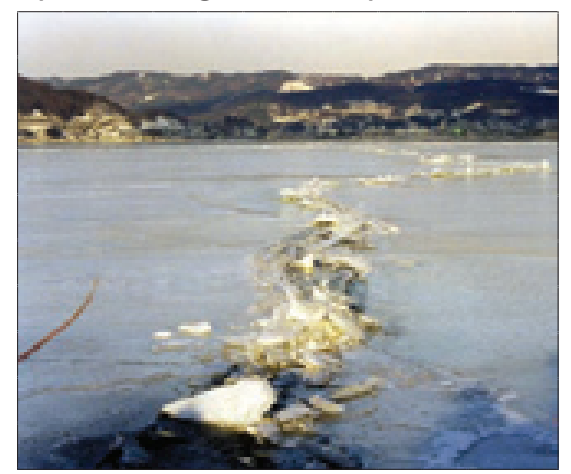

Fig. 3: The "Omiwatari" phenomenon, described as "a bridge crossing the lake" on Lake Suwa (January 31, 1998).

ter temperatures were estimated for central Japan from 1444 to 1995 (Fig. 4). Although the lake freezing records are not continuous from the late seventeenth century to the nineteenth century, a clear warming

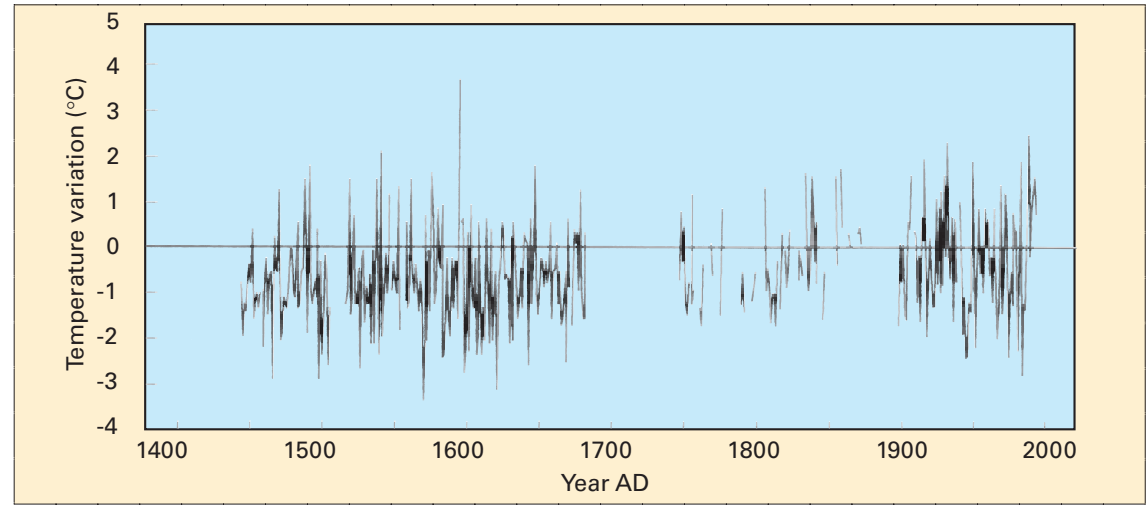

Fig. 4: Interannual variations in December-January temperatures at Lake Suwa during 14441870 (reconstructed) and 1891-1995 (observed)

trend stands out in Figure 4, during the final stage of the Little Ice Age from the 1750 s to the 1850 s. On the other hand, the coldest period since the $15^{\text {th }}$ century was the early 1600 s, when reconstructed mean winter temperatures were about 1 to $1.5^{\circ} \mathrm{C}$ lower than at present (1961-1990). In order to verify the reliability of this estimated temperature series, we made some comparisons with other climate reconstructions on the basis of different proxy records, such as tree-rings (Sweda andTakeda, 1994). The results show a relatively good agreement with our winter temperature reconstruction. As for the longterm freezing records of Lake Suwa, the reliability of yearly records is still not assured for some periods. More effort should be made in the verification and calibration of these valuable documentary records. Com- parison with instrumentally observed data during the overlapping period is a vital prerequisite to producing a robust reconstruction (Konnen et al., 2002).

\section{REFERENCES}

Konnen, G.P., Zaiki, M., Baede, A.P.M., Mikami,T., Jones, P.D. and Tsukahara,T., 2002: Pre-1872 extension of the Japanese instrumental meteorological observation back to 1819 . Journal of Climate, in press.

Mikami, T., 1988: Climatic reconstruction in historical times based on weather records. Geogr. Rev. Japan (Ser. B), 61, 14-22.

Mikami, T., 1996: Long term variations of summer temperatures in Tokyo since 1721. Geogr. Rep. of Tokyo Metropolitan Univ., 31, 157-165.

Mikami, T.,1999: Quantitative climatic reconstruction in Japan based on historical documents. Bull. Of the National Museum of Japanese History, 81, $41-50$

Sweda, T. and Takeda, S., 1994: Construction of an 800-year-long CHAMAECYPARIS dendrochronology for central Japan. Dendrochronologia, 11, 79-86.

\section{Years of Temperature History in China}

Quansheng Ge, Jingyun Zheng, Xueain Zhang

Institute of Geographic Sciences and Natural Resources Research (IGSNRR), Chinese Academy of Sciences (CAS), Beijing 100101, China;gegs@igsnrr.ac.cn, zhengjy@igsnrr.ac.cn, zhangxq@igsnrr.ac.cn

In the $8^{\text {th }}$ lunar month (10/9-9/10), $A D$ 17, Wang Mang went to the southern suburb in person to build a large DOU (a kind of ancient container). On the day of building the DOU, it was so frosty that many officials and horses froze to death. (from Hanshu, History of the Han Dynasty).

Over 2000 years of records documenting cold and warm events are archived at the Institute of Geographic Sciences and Natural Resources Research (IGSNRR), Chinese Academy of Sciences. These records include both direct and indirect, or proxy evidence.
As described by Pfister et al (this issue), direct evidence refers to observations of temperature and its impact on humans, as illustrated above. Indirect, or proxy evidence, refers to information on plant growth and other phenological observations, agricultural data including not only sowing and harvesting times but also changes in the northern boundary of tropical and sub-tropical crops (e.g. citrus, tea, bamboo), and observed snow and ice features. This may include the first and last frost and snowfall dates, and the duration of frost, snow or ice cover. The following excerpts illustrate indirect, or proxy evidence.

In the $11^{\text {th }}$ lunar month of the 2nd year in the Guangqi Reign, Tang Dynasty (886), Huainan was continually cloudy with rain and snow until the 2nd lunar month of the next year. (From Xintang Shu,History of the New-Tang Dynasty), Wu-Xing-Zhi. The records of Five Elements, Vol. 3). In the $2^{\text {nd }}$ year of theDazhongxiangfu Reign, Northern Song Dynasty (1009), Jingshi (the capital city) was warm and without rivers freezing. (from Songshi, History of the Song Dynasty, Wu-XingZhi, The Records of Five Elements). 
Usually both categories of information are found within the same source, as can be seen in the example below.

In the $12^{\text {th }}$ lunar month of the 1 st year in the Tianxi Reign, Northern Song Dynasty (1017), Jingshi (the capital city) suffered from heavy snows and the weather was bitter cold, some people froze to death and dead bodies were exposed on the roadsides. From Songshi (History of the Song Dynasty), Wu-Xing-Zhi (The Records of Five Elements)

Figure 1a shows estimated temperatures for the winter halfyear (October through April) over the last two thousand years for the middle and lower reaches of the Yellow River and the Yangtze River. The time resolution of Figure $1 \mathrm{a}$ is 30 years over the past 2000 years, and that for the two sub-periods 961-1110 (Fig. 1b) and 1501-1999 (Fig. 1c) is 10 years. The standard errors of the reconstructions are $\pm 0.7^{\circ} \mathrm{C}$ to $\pm 1.5^{\circ} \mathrm{C}$ for Figure $1 \mathrm{a}$ and between $\pm 0.6^{\circ} \mathrm{C}$ to $\pm 1.5^{\circ} \mathrm{C}$ for Figures $1 \mathrm{~b}$ and $1 \mathrm{c}$. The curves for the pre-instrumental period (prior to 1951) are primarily based on phenological observations, crop distribution data, and snow-cover duration. From 1951 onwards it is based on instrumental series.

Producing this reconstruction involved two steps. Initially, temperatures were estimated from phenological observations for both the pre-instrumental and the instrumental periods. The data from the instrumental period were calibrated using regression techniques. Subsequently, the average temperature of the region was calculated using data from 20 meteorological stations. Finally, temperatures at individual locations were compared with the regional temperature using regression techniques.

The regional temperature trends assessed in this way (Fig. 1a) (Ge et al., 2002), are consistent with those reconstructed from other natural proxy data in China, such as pollen, tree rings, and lake sediments. They are also consistent with reconstructions of glacier fluctuations in western China, periglacial development

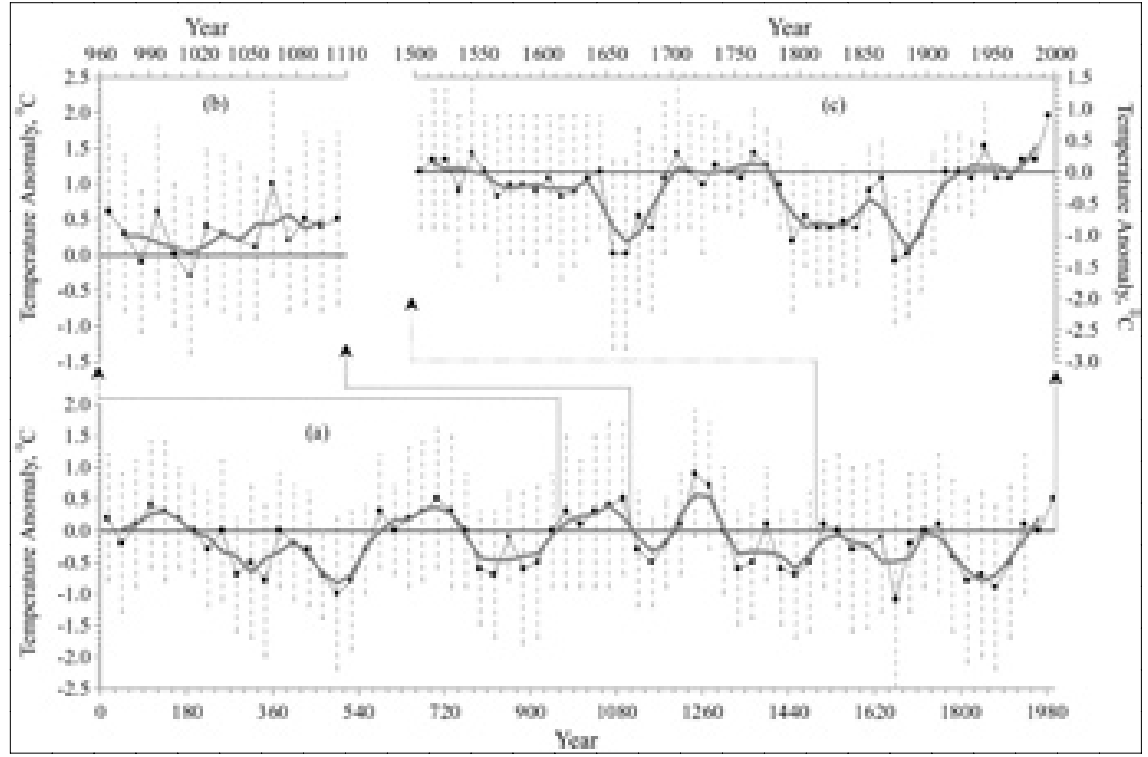

Fig. 1 Winter-half-year temperature anomaly change for the middle and lower reaches of the Yellow River and the Yangtze River, with (a) 30-year resolution during the past 2000 years, or with (b) 10-year resolution during 961-1110, or with (c) 10 year resolution during 1501-1999. (Black line: Winter-half-year temperature anomaly; Gray line: 3-point running mean; Dashed lines: Error bars)

and the development of paleosoil in northern China. An inspection of the reconstructed temperature series (Fig. 1a) reveals the following characteristics. From AD 0 to about $A D 490$, the winter half year became cooler with a rate of $0.17^{\circ} \mathrm{C}$ per century. Around AD 500 the winter half year was about $1^{\circ} \mathrm{C}$ colder than the 1951-1980 (modern) mean. From AD 570 to AD 1310 the winter half year underwent a slow warming of $0.04^{\circ} \mathrm{C}$ per century. Around 1260 it was between 0.3 and $0.6^{\circ} \mathrm{C}$ warmer than the modern mean. An analysis of ten year periods shows that the warmest decade, around 1250, was about $0.9^{\circ} \mathrm{C}$ warmer above the modern mean. After 1310 the temperature plummeted at a rate of $0.10^{\circ} \mathrm{C}$ per century. Temperatures during four distinct cold periods were 0.6$0.9^{\circ} \mathrm{C}$ lower than the modern mean :1321-1350 $\left(-0.6^{\circ} \mathrm{C}\right), 1441-1470$ ($\left.0.7^{\circ} \mathrm{C}\right), 1651-1680\left(-1.1^{\circ} \mathrm{C}\right)$, and $1861-$ $1890\left(-0.9^{\circ} \mathrm{C}\right)$. The 1650 s were even $1.1^{\circ} \mathrm{C}$ below the modern mean. Subsequently, the winter half year got warmer. Over the last two decades of the last millennium the warming was particularly pronounced. 19811999, the average temperature from October to April is already $0.5^{\circ} \mathrm{C}$ higher than the 1951-1980 mean. The transitions between cold and warm periods during the last 200 years often involved rapid changes.
The low-frequency (30 year) temperature trends assessed for the past millennium (Fig. 1a) are similar to others reconstructed for the northern hemisphere (Jones et al., 1998; Mann et al., 1999; Crowley et al., 2000). In particular, our data indicates that the little Ice Age, a long cooling trend from the High Middle Ages to about 1860 well documented in Europe, was also evident in China. On the other hand, the magnitude of temperature fluctuations reconstructed for China is greater than that found in northern hemisphere mean climate reconstructions (Mann et al., 1999). In this context, we emphasize that the $20^{\text {th }}$-century in China is still within the uncertainty range of the variability reconstructed for the past 2000 years.

\section{REFERENCES}

Crowley, T. J. and Lowery T. S., 2000: How warm was the Medieval Warm Period? AMBIO, 29 (1): 51-54.

Ge, 0., Zheng, J. and Fang, X., et al., 2002: Winter Half-Year Temperature Reconstruction for the Middle and Lower Reaches of the Yellow River and Yangtze River during the Past 2000 Years. The Holocene (Accepted)

Jones, P. D., Briffa, K. R., and Barnett, T. P., et al., 1998: High-resolution palaeoclimate records for the last millennium: Interpretation, integration and comparison with General Circulation Model control-run temperatures. The Holocene, 8: 455-471.

Mann, M. E., Bradley, R. S. and Hughes, M. K., 1999: Northern Hemisphere temperature during the past Millennium: Inferences, Uncertainties, and Limitations. Geophysical Research Letters, 26(6): 759-762. 


\title{
Documentary Records of Past Climate and Tropical Cyclones from the Southeastern United States
}

\author{
CARY J. Mock \\ Department of Geography, University of South Carolina, Columbia, South Carolina, USA; mockcj@sc.edu
}

Climatic changes at interannual and decadal timescales are of important concern to residents of the Southeastern United States. This region has a low water-storage capacity and is extraordinarily susceptible to prolonged drought and fire hazards. Superimposed within interannual climatic variations are high-magnitude flood, snowstorm, and hurricane hazards that occur at daily to weekly timescales. Winter polar outbreaks and killing frosts also occasionally occur, severely impacting the fruit tree industry (Stahle, 1990). Modern climate studies indicate that teleconnections, such as ENSO, the PNA, and the NAO, substantially influence southeastern U.S. climate. A longer perspective is critical to fully investigate the temporal and spatial stability of these important modes of climatic variability.

Documentary weather records are available for several areas of the Southeastern United States for the past several hundred years prior to the establishment of the first organized weather bureau in 1871. These records include hundreds of plantation diaries, numerous newspapers, and early instrumental records. The first systematic meteorological observations conducted in the United States began in Charleston, South Carolina in 1838 by Dr. John Lining (Aldredge, 1940). The abundant climatic details of plantation manuscripts for the Southeast are well-known to historians, with many daily records containing weather observations. Yet, despite their huge potential, manuscripts in the Southeast have only been recently utilized for climate reconstruction.

Clearly, the reliability of historical reports cannot be taken at face value, with some materials actually being inappropriate for climate reconstruction. Original sources were used if available, as typescript copies may contain erroneous edited information. Written descriptions of severe storms and climate may also reflect

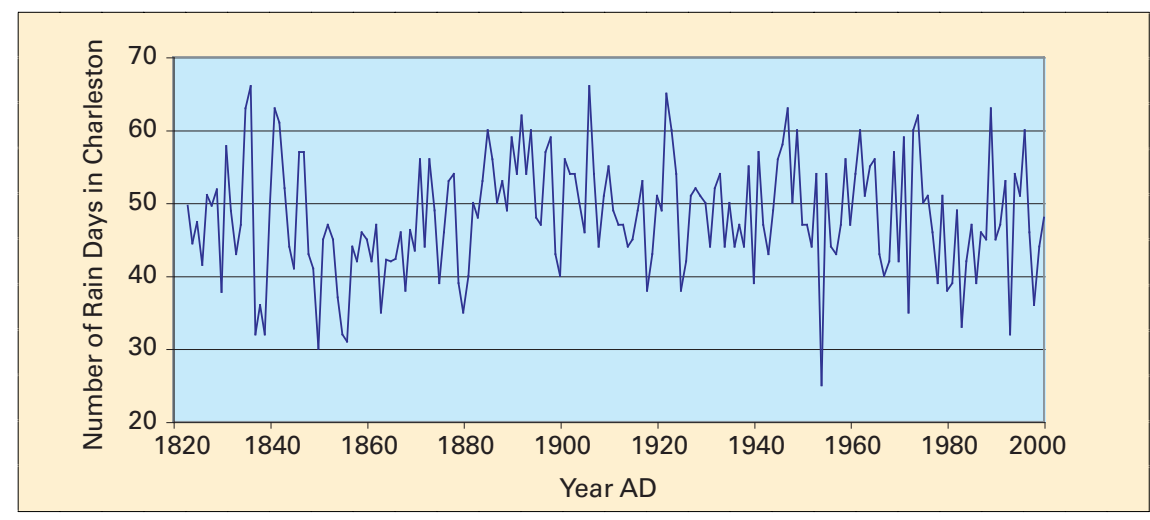

Fig. 1: Annual June-September precipitation frequencies for Charleston, South Carolina, USA. The horizontal reference line indicates the modern climatic normal of rain days from 1971-2000.

individual biases from diarists. Daily historical data were collected whenever possible in order to properly assess data quality, as these data reveal important aspects such as diurnal temperature ranges and the timing of precipitation events. Discontinuities were searched carefully in time series of greater than ten years, and any suspect data were not included in our reconstructions. A major goal of our research was to calibrate and present historical climate data in a format that is closely compatible with the modern record.

Two examples of historical reconstructions for Charleston, South Carolina are presented in the following: 1) June-September (warm-season) precipitation frequency and 2) tropical cyclone frequency. Precipitation frequencies from both early instrumental and documentary evidence are among the most reliable and plentiful climatic indicators for the historical climatologist, as these reconstructions can be directly compared with modern climatic data (Mock, 1991). Precipitation frequencies also more accurately reflect homogeneous signals that respond to changes in synoptic-scale atmospheric circulation (Woodhouse and Meko, 1997). With plentiful documentary data within the city limits, Charleston presents an ideal location to reconstruct frequencies of measurable precipitation, defined as days on which precipitation was at least $0.0254 \mathrm{~cm}$ (0.01 inches). The Charleston tropical cyclone frequency record is the longest of its kind that is reconstructed for a location in the United States. Its record is continuous since 1778, augmenting the Atlantic Basin historical hurricane database (Fernández-Partagás and Diaz, 1996).

A complete reconstruction of June-September precipitation frequencies for Charleston extends back to 1823 (Fig. 1). The twentieth century record reveals both interannual and decadal variability, with somewhat greater precipitation during most of the first half of the twentieth century. A distinctive period of lower precipitation is evident for much of the period from 1845-1870, and this activity is unprecedented relative to the twentieth century record. Such a persistent period of drought most likely had dramatic climate impacts on the antebellum plantation agriculture and lifestyle. Although underestimation of precipitation is a common problem in historical climatic reconstructions, the author is confident that this is not a problem for the 1845-1870 period, as the quality of the documentary data is clearly superior and more plentiful than the relatively wetter pre-1845 period.

Results of the tropical cyclone frequency reconstruction for Charleston are displayed for each year and by a 5-year centered moving average (Fig. 2). The number of storms per 


\section{Science Highlights}

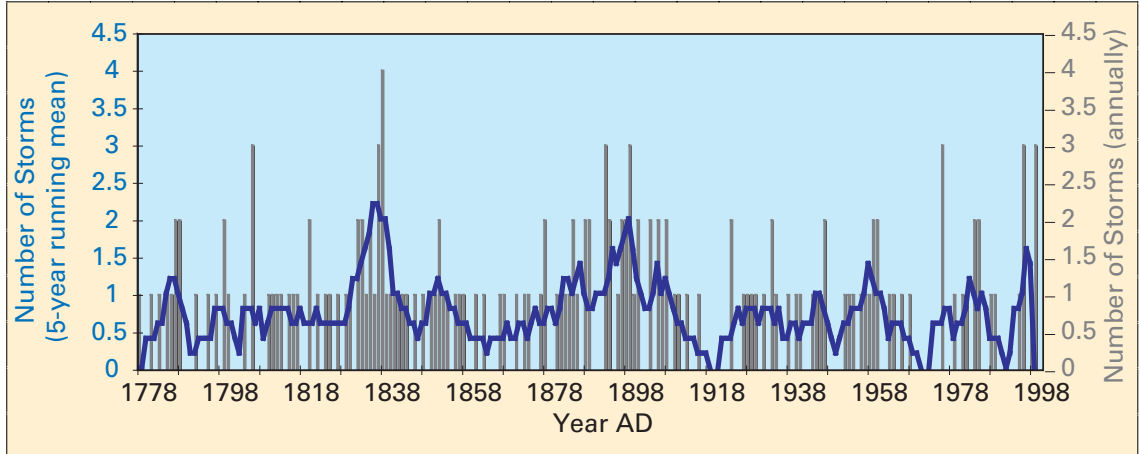

Fig. 2: Time series of tropical cyclone frequencies for South Carolina, centered at Charleston, from 1778-2000. The red vertical bars represent annual frequencies while the blue line represents a 5-year running mean.

year varied from zero to four, but mostly from zero to two. Details of 68 storms were analyzed for the 1778-1870 period, with 25 of them being newly documented storms. A calculated mean recurrence interval for 1778-1870 suggests significant tropical storm impact on Charleston every 1.30 years, clearly lower than the interval of 1.80 years that dominates during most of the late nineteenth and twentieth centuries. The 5-year running mean indicates that much of this greater tropical cyclone activity occurred in the 1830s. This decade is clearly the most active in the entire time series. In particular, 1838 had four storms, the most annually for the entire record, and two of the four storms occurred in June.

Documentary evidence of the Southeastern United States, although not as lengthy as in Europe and Asia, provides valuable information of high resolution climate back into the eighteenth century, well before the modern instrumental record. It contributes to other existing high resolution paleoclimatic and paleohurricane databases for North America, providing further insight on the spatial variations and causes of natural climatic variability. Aside from tree-rings, that are sensitive mostly to late-spring rainfall and drought, these historical data are the only evidence of past climate that can provide seasonal quantitative reconstructions for the region. Historical climate records from the Southeastern United States can also aid in testing and verifying general circulation model simulations of the past several centuries.

\section{References}

Aldredge, R.C. 1940: Weather observers and observations at Charleston, South Carolina from 16701871. Historical Appendix of the Year Book of the City of Charleston for the Year 1940: 190-257.

Fernández-Partagás, J. and Diaz, H.F., 1996: Atlantic hurricanes in the second half of the nineteenth century. Bulletin of the American Meteorological Society, 77: 2899-2906.

Mock, C.J., 1991: Historical evidence of a cold dry summer in the northeastern Great Basin and adjacent Rocky Mountains during the summer of 1849. Climatic Change, 18: 37-66.

Stahle, D.W., 1990: The Tree-Ring Record of False Spring in the Southcentral United States. Ph.D. Dissertation, Arizona State University. Tempe, AZ, U.S.A.

Woodhouse, C.A. and Meko, D.M., 1997: Number of winter precipitation days reconstructed from Southwestern tree rings. Journal of Climate $\mathbf{1 0}$ 2663-2669.

\section{Floods in Europe - A Look into the Past}

Rudolf Brázdil ${ }^{1}$, Rüdiger Glaser ${ }^{2}$, Christian Pfister ${ }^{3}$ and Heiko Stangl ${ }^{2}$

${ }_{1}^{1}$ Department of Geography, Masaryk University, Brno, The Czech Republic; brazdil@sci.muni.cz

2 Department of Geography, University of Heidelberg, Germany; ruediger.glaser@urz.uni-hd.de; heiko.stangl@urz.uni-hd.de

3 National Center of Competence in Research on Climate (NCCR), Institute of History, University of Bern, Switzerland; pfister@hist.unibe.ch

During the 1990s, floods (e.g. 1993 and 1995 on the Rhine and the Meuse, 1997 on the Morava and the Oder and 2002 in Central Europe) have been among the most devastating disasters in Europe resulting in losses of human lives and substantial damage, disrupting community life and generating collective stress and widespread fear. The deluge of August 2002 in Central Europe caused such staggering losses that Germany's large economy has struggled to cope with the costs of recovery. The issue of whether and how such disasters might be related to the greenhouse effect and global warming is repeatedly put on the agenda. However, the number of well-documented cases is too small for conclusions to be drawn. In Europe, early water gauge measurements started during the eighteenth century (e.g.
1708 in Zurich) but for most rivers, instrumental observations are only available for the twentieth century. This is insufficient for an assessment of flood frequency changes in the presence of substantial natural climate variability. Documentary evidence about severe flood events can substantially increase the number of cases available for analysis.

\section{Documentary evidence on floods}

Two types of evidence - written reports and flood marks - need to be distinguished.

Reports on severe floods go back to the Middle Ages. They are documented in sources such as annals, chronicles, memoirs, diaries, letters, newspapers or economic records. For example, the first reliable report about a flood in Prague was written by the chronicler Kosmas (Brázdil,
1998): "In the year of our Lord 1118 in the month of September there was such a flood as, I think, it has not been on the Earth since the Deluge. This river of ours, the VItava, suddenly broke out of its bed - how many villages, how many houses in the suburbs, huts and churches did it take away! At other times, although it happens rarely, the water reaches only the floor of the bridge, but this flood rose to a height of ten ells [i.e. approximately $6 \mathrm{~m}$ ] over the bridge." This chronicler tried to quantify the magnitude of the event by relating the highest water level to the altitude of the bridge (one of the predecessors of the recent wellknown Charles bridge).

Some reports just mention the occurrence of an event. Others may include description on the causes of the flood, its magnitude and duration as well as detailed accounts on 
the damage caused. Often, a mark is placed on a building (e.g. houses, gateways, bridges - see Fig. 1) or on a rock to document the highest water level during an event. Flood marks may be used to estimate the maximum discharge rate of an event and to assess its spatial dimension using a digital terrain model. However, this requires detailed knowledge of land-use, landforms and the riverbed, which are often not known for er territorial units. They are related to supra-regional synoptic patterns such as cyclones or troughs, causing a continuous precipitation for several consecutive days (type ii) or sudden warming (types iii and iv). Floods from snow melting depend on the water equivalent of the snow cover, the extent of frozen soil and the intensity of warming combined with precipitation to contribute to a cumulative impact. Ice damming re-

Table 1. Intensity classification of historical floods (Brázdil et al., 1999; Sturm et al., 2001)

\begin{tabular}{|c|l|l|l|}
\hline Level & Classification & \multicolumn{1}{|c|}{ Primary Indicators } & Secondary Indicators \\
\hline $\mathbf{1}$ & $\begin{array}{l}\text { smaller, regional } \\
\text { flood }\end{array}$ & $\begin{array}{l}\text { little damage, e.g. fields and gardens close to the } \\
\text { river, wood supplies that were stored close to the } \\
\text { river are moved to another place }\end{array}$ & short flooding \\
\hline $\mathbf{2}$ & $\begin{array}{l}\text { above average or } \\
\text { supra-regional flood }\end{array}$ & $\begin{array}{l}\text { damages on buildings and constructions related to } \\
\text { the water like dams, weirs, footbridges, bridges and } \\
\text { buildings close to the river like mills etc.; water in } \\
\text { buildings }\end{array}$ & $\begin{array}{l}\text { flood of average duration, severe damages } \\
\text { to fields and gardens close to the river, } \\
\text { loss of animals and sometimes people }\end{array}$ \\
\hline $\mathbf{3}$ & $\begin{array}{l}\text { above average or } \\
\text { supra-regional flood } \\
\text { on a disastrous } \\
\text { scale }\end{array}$ & $\begin{array}{l}\text { severe damages on buildings and constructions } \\
\text { related to the water i.e. dams, weirs, footbridges, } \\
\text { bridges and buildings close to the river like mills } \\
\text { etc, water in buildings; in part, buildings are } \\
\text { completely destroyed or torn away by the flood }\end{array}$ & $\begin{array}{l}\text { longer flood duration, days or weeks; } \\
\text { severe damages on fields and gardens } \\
\text { lose the river, extensive loss of animals } \\
\text { and people; morphodynamic processes } \\
\text { like sand sedimentation cause lasting } \\
\text { damages and change the surface structure }\end{array}$ \\
\hline
\end{tabular}

the remote past. An evaluation of all evidence from different sources often allows the classification of events according to three (Table 1) or four classes (Pfister 1999) in order to set up semi-quantitative time series.

In many cases the evidence is sufficient to yield information on seasonality, severity and impacts. Scientific objectives of historical flood analysis include the following points of view: assessing the size of extreme flooding, classification of extreme floods according to season and causes and assessing long-term changes in flood frequency under conditions of a "natural" climate.

\section{Flood Typology in Central Europe} To characterise the severity of a flood, its return period corresponding to culmination discharge rate is calculated (so-called N-year water). Four basic types of events may be distinguished according to their meteorological causes: (i) short but intensive downpours or cloudbursts (flash floods), (ii) long-lasting continuous rainfalls, (iii) snow-melt and (iv) ice damming.

The so-called flash floods occur on a local scale and may have disastrous local impacts as they are connected with heavy precipitation during convectional storms. The other two types of floods affect larg- sults from a sudden warming in the upstream area of a river following a long period of very low temperatures. The water then breaks up the ice. Ice clods may pile up and dam the water or damage bridges (such as occurred in February 1784 in parts of Germany and Bohemia).

The described causes of floods often overlap, and they are related to other physical-geographical factors such as the saturation of the catchment area, vegetation, and with anthropogenic factors such as

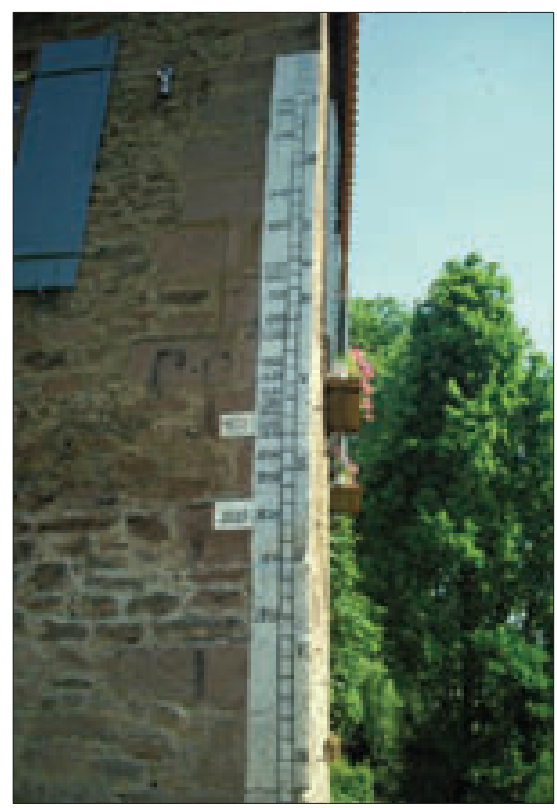

Fig. 1: Flood marks at Wertheim on the tributary of the Tauber river to the Main (Glaser, 2001) the building of water structures ( dams, reservoirs, weirs), land use, and changes in riverbeds.

\section{The frequency of floods in a natural climate}

The issue of whether clusters of severe floods may occur in a natural climate is crucial for detecting a fingerprint of the greenhouse effect in the records of extreme events.

Progress in historical climatology achieved during the 1990s. Besides the detailed investigations of some catastrophic past floods (e.g. July 1342, February 1784), long flood chronologies were set up for different rivers in Europe (Fig. 2). Recently, the dynamic and socio-economic aspects of historical floods in Central Europe are analyzed in the framework of the European research programme FLOODRISK (Wanner et al., 2002). Historical flood events for Germany based on documentary evidence since AD 1500 were recorded in three severity classes and related to reconstructed air pressure and precipitation data. Decadal scale variability became apparent in the recording of all large river systems, indicating winter periods with higher (e.g., 1630-1700 and 1830-1880) and lower (e.g., 1720-1780 and 1880-1930) flood frequencies. The correlation between the winter season frequencies of the different river systems is non-stationary, and a discernable long-term trend is not evident. The circulation analysis based on a long-term Atlantic-European surface air pressure data showed that the humidity transport from the Atlantic Ocean to the European continent is a key factor conditioning flood situations.

On the other hand, a significant decrease in the number and in the severity of floods was observed for the VItava river at Prague and for the Elbe river at Decín (both the Czech Republic) from the second half of the nineteenth century to the end of the twentieth century, mainly due to significant reduction of floods from February to April (Brázdil, 1998). The recent catastrophic flood in August 2002, estimated for the Vltava at Prague to be a 500-year event, came unexpectedly after a very quiet period of the twentieth century in both 


\section{Science Highlights}

catchment areas. Its magnitude was probably comparable to one from the same area in July 1432, which was considered to be a "millennial flood".

For historical and recent floods, their social dimension is important. Consequences caused by historical floods can be divided into two groups (Wanner et al., 2002, see table 1): (i) short-term consequences (e.g. destruction of houses, streets and bridges, breakdown of water supply) (ii) medium-term consequences (e.g. shut down of industrial plants, soaked pastures, animal diseases).

Confronted with the harm caused by catastrophic floods, people are eager to get specific information and rapid support. Examples from Switzerland show that in addition to assistance from political authorities, media fund raising campaigns have been very successful. It becomes apparent that risk management, when consistently utilised by the political authorities, has strengthened the bonds of national unity.

\section{Outlook}

Historical climatology contributed significantly to the extension of our knowledge about historical floods in Europe for the pre-instrumental period. Flood frequency, seasonality, severity and impacts, as well as trends related to anthropogenic cli-

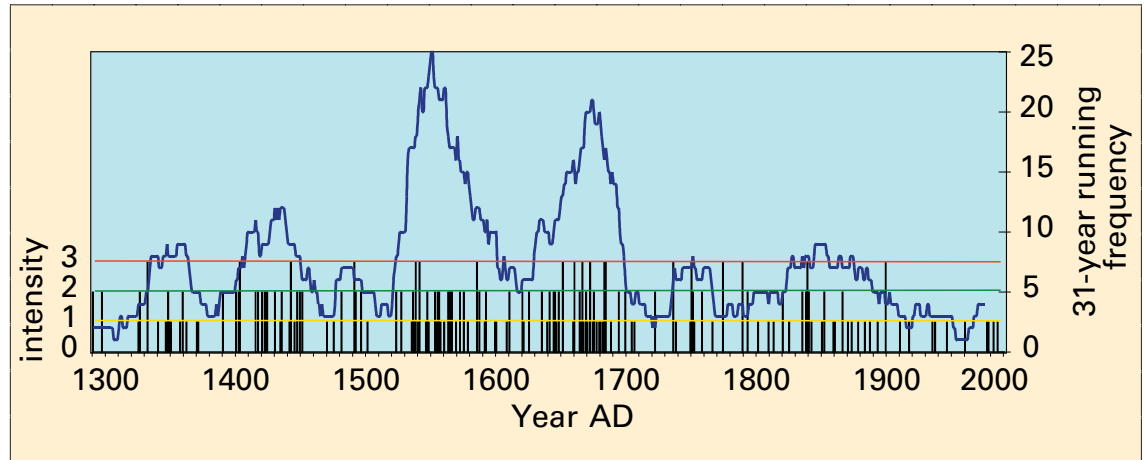

Fig. 2: Flood patterns of the river Pegnitz in Nuremberg (Germany) from 1300 to 2000. The altitude of the bars is proportional to the severity of the events (see Table 1). The curve displays 31-year running averages. Two distinct phases of high flood frequency stand out during the main phase of the Little Ice Age between 1550 and 1700.

mate change, are all prime subjects for study by historical climatologists. Some historical events serve as analogues for recent floods and well documented recent events are important for understanding similar floods in the past. In these studies, variable anthropogenic effects in the catchment areas such as changes in land use, in riverbeds, in stream regulations and infrastructure (dams, reservoirs, etc.) should be taken into consideration. The value of historical flood evidence lies in its use for flood risk assessments and in helping to prepare flood-prone zones for maximum floods that are documented within the last centuries. These long-term records may reduce uncertainty in hydrological analyses and decrease losses of human lives and property.

\section{REFERENCES}

Brázdil, R., 1998: The history of floods on the rivers Elbe and VItava in Bohemia. Erfurter Geographische Studien 7: 93-108.

Brázdil, R., Glaser, R., Pfister, C., Dobrovolný, P. Antoine, J.-M., Barriendos, M., Camuffo, D. Deutsch, M., Enzi, S., Guidoboni, E., Kotyza, 0. and Rodrigo, F. S., 1999: Flood events of selected European rivers in the sixteenth century. Climatic Change 43: 239-285.

Glaser, R., 2001: Klimageschichte Mitteleuropas. 1000 Jahre Wetter, Klima, Katastrophen. Primus Verlag, Darmstadt, $227 \mathrm{pp}$.

Pfister, C., 1999: Wetternachhersage. 500 Jahre Klimavariationen und Naturkatastrophen (14961995). Verlag Paul Haupt, Bern, Stuttgart, Wien, 304 pp.

Wanner, H., Beck, C., Brázdil, R., Casty, C., Deutsch, M., Glaser, R., Jacobeit, J., Luterbacher, J., Pfister, C., Pohl, S., Sturm, K., Werner, P. C. and Xoplaki, E., 2002: Dynamic and socioeconomic aspects of historical floods in Central Europe. Bulletin of the American Meteorological Society, submitted.

For full references please consult:

www.pages-igbp.org/products/newsletters/ref2002_3.html

\section{Reconstructions of Minimum Glacier Extensions in the Swiss Alps}

\author{
Hanspeter Holzhauser ${ }^{1}$ and Heinz J. Zumbühl ${ }^{2}$ \\ 1 Institut of Geography, University of Zürich, Switzerland; holzi@geo.unizh.ch \\ ${ }^{2}$ Institut of Geography, University of Bern, Switzerland; zumbuehl@giub.unibe.ch
}

The advance and retreat of alpine glaciers indirectly reflects the natural variability of Holocene climate. Using different methods (analysis of historical sources, dating of trees and soil; Zumbühl and Holzhauser, 1988), we aim to reconstruct glacial fluctuations in order to verify Holocene climate variation.

In order to correctly interpret the current rapid glacier retreat in contrast to the previous maximum extent in 1850/60, it is important to know the Holocene minimum and maximum extent of alpine glaciers. The maximum advance of post- ice age alpine glaciers is well-documented by the high mark of moraines. In contrast, the glacial minimum, that is, the minimal glacial extent between two advances, is not well documented by moraines and is therefore difficult to determine.

The glacial minimum can be demonstrated and dated either by fossil soils and trees that surface at the melting ice edge (Holzhauser, 1984), or by the use of historical documents (Zumbühl, 1980). We provide two examples of how the glacial minimum during the Little Ice Age could be reconstructed using appropriate historical pictorial sources.
The Great Aletsch glacier in 1755

Due to a legal dispute between the Wallis townships of Ried-Mörel, Mörel und Bitsch on one side, and Naters und Rischinen on the other side, we know the extent of the Great Aletsch glacier in the middle of the $18^{\text {th }}$ century. The parties concerned disputed the ownership of some grassland on the western slope of the Riederhorn mountain. An initial court hearing took place in 1684, and a second hearing took place 70 years later from 1754 to 1755. Three generations later, from 1855 to 1856 , a third hearing took place. 


\section{Science Highlights}

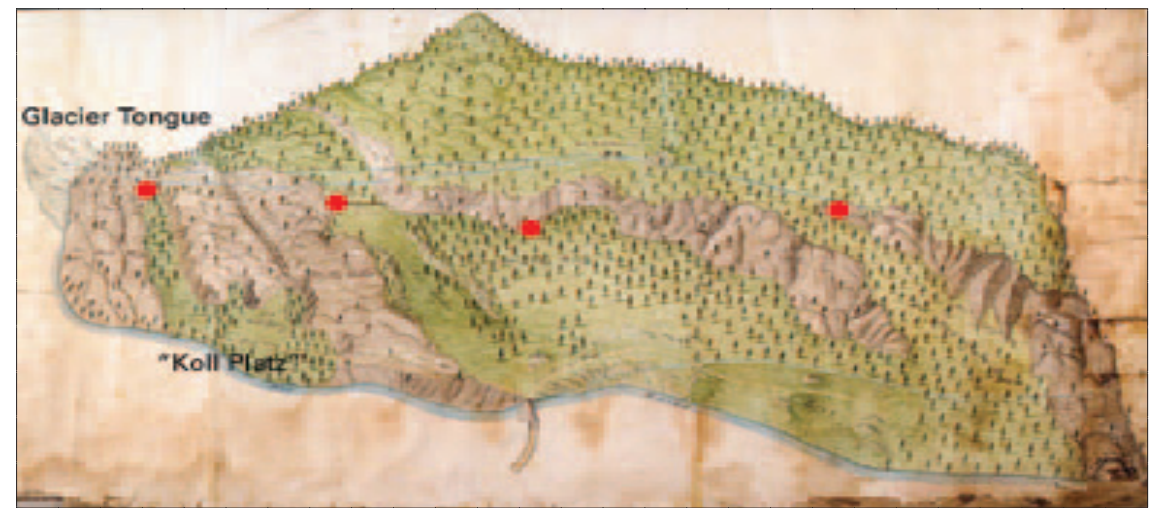

Fig. 1: The tongue of the Great Aletsch glacier in 1755 (middle left). This diagram, made in 1855/ 56 , is a faithful reproduction of the original diagram from 1755. The year numbers mentioned in the text are circled in red (124 x $67 \mathrm{~cm}$; Kantonsarchiv Sion, Plan divers, No. 42).

The complete records of this legal dispute have been kept in the town archives of Mörel and Naters (Holzhauser, 1984). In addition to written documents, it turns out that there is also a map from the Wallis cantonal archive in Sitten (Fig. 1), on which the western flank of the Riederhorn (clearly recognizable as the highest peak) is depicted. The Massa, the outflow of the Great Aletsch glacier, forms the lower border of the area portrayed. Fortunately, on the extreme left side of the picture, the ilustrator has depicted the tongue of the Great Aletsch glacier. The area is heavily forested, as evidenced by the numerous stylized trees even in the direct vicinity of the tongue of the glacier, on "Koll Platz." This observation is especially important for the interpretation of glacial history.

The connection between the map and the court records was not initially evident because the documents were archived in different locations. Also, the diagram was not dated. In order to assign a date to the glacier depicted, it was necessary to have a more exact age for the map. Analysis of the court records showed that first, the area referred to in the court records was identical with that pictured on the map, and second, the local names on the diagram (e.g. "Koll Platz") were also mentioned in the court records. Upon closer analysis of the map, four numbers corresponding to years could be recognized; these lay approximately in a straight line. From left to right, these are: $1756,17+56,+1755$ and 1756 (Fig. 1). The cross by the middle numbers led us to suspect that they could be boundary markers. This suspicion was confirmed through the analysis of written documents. In the court verdict from $1754 / 55$, it was recorded that the boundaries must be carved into the rock. In the last court hearing from 1855/56, the year numbers were recorded on the diagram using the same notation as was used to carve them on the actual site. As to when the diagram originated, it must be the date of the last court hearing, namely $1855 / 56$. However, this date is unsatisfactory, because in the middle of the $19^{\text {th }}$ century, the glacier was demonstrably greater than pictured on the map. How can this paradox be resolved?

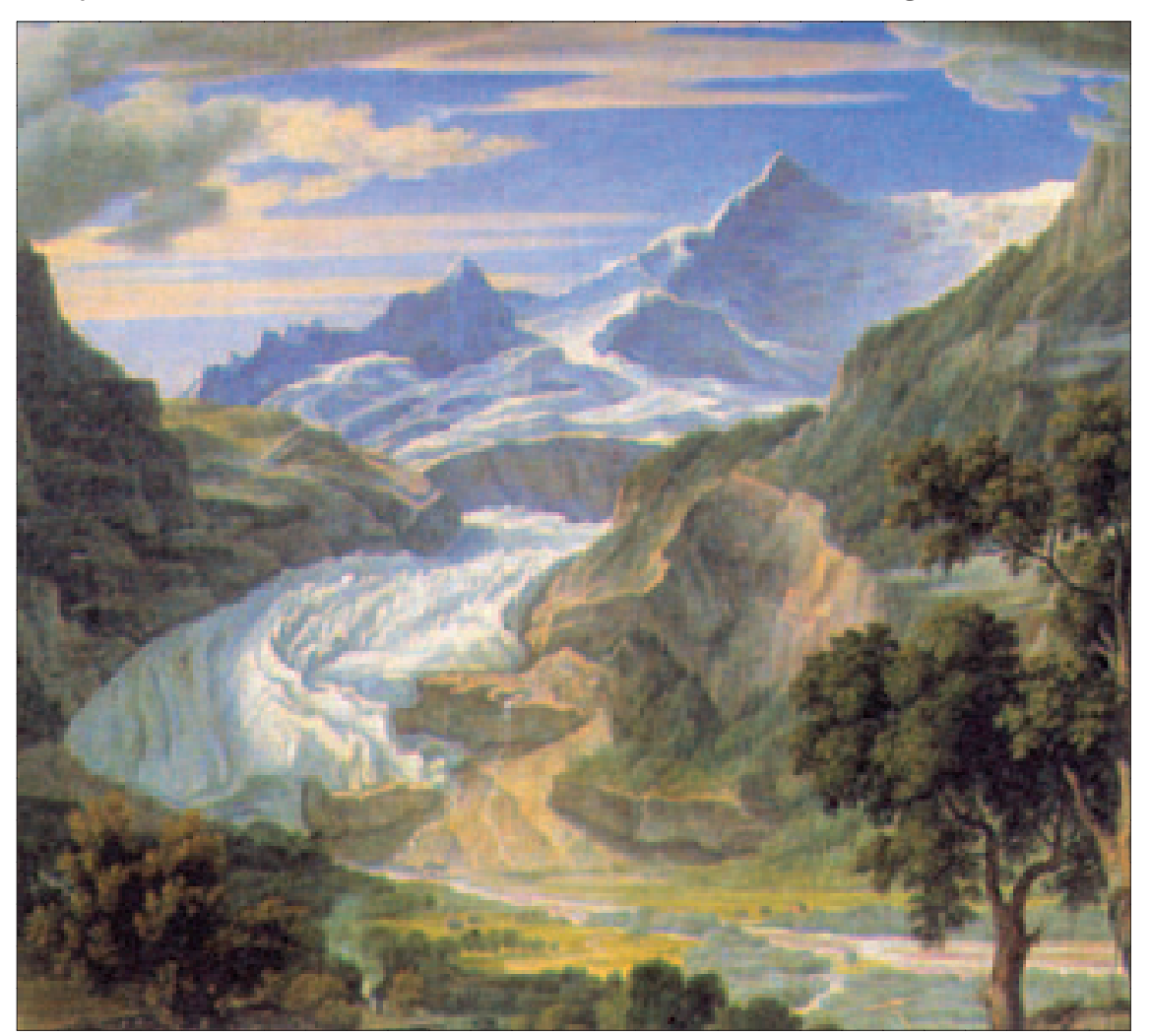

Fig. 2: The Lower Grinde/wald glacier in 1794, ending on the Schopffelsen. Oil painting by

Josef Anton Koch (88,5 x 122,5 cm; Muzeum Narodowe we Wroclawiu, Wroclaw Polen).

The solution was found, in another map in the town of Naters. This map is very similar to the one mentioned above, except that it consists of India ink on parchment, is not colored and does not include any year numbers. Apparently this parchment diagram dates from $1754 / 55$, when it was submitted by the town of Naters to the court. It is the one often mentioned in the court records from $1855 / 56$. The map pictured in Figure 1 is thus a later, faithful reproduction of the original parchment, and was used by the towns of Ried-Mörel, Mörel and Bitsch during the court hearing of $1855 / 56$. Thus it is also clear why the extent of the glacier tongue in the reproduction corresponds not to that of the glacier in $1855 / 56$, but rather to that of 1755 . The topography is astonishingly well recorded. Therefore it is possible to relatively accurately estimate the extent of the glacier tongue in 1755 . The Great Aletsch glacier at that time is of a magnitude comparable to that of 1890 , and was thus 900 to 1000 meters shorter than during its last maximum extension during the Little Ice Age in 1859/60. During this time, the end of the glacier reached 


\section{Science Highlights}

"Koll Platz". As mentioned above, this area is forested on the diagram. This implies that the Great Aletsch glacier not reached this extension since long before the middle of the $18^{\text {th }}$ century.

\section{The Lower Grindelwald glacier between 1794 and 1826}

During the Little Ice Age, the tongue of the Lower Grindelwald glacier often advanced into the valley, ending near the town of Grindelwald. Since the end of the $18^{\text {th }}$ century, this glacier has thus been one of the most well-known and most frequently visited glaciers in the entire alpine region. This glacier is also exceptional in that it is represented in numerous (more than 360 pictorial sources before 1900) historical pictorial and written sources, some of which are of high quality. The abundance of sources for the last 300 years facilitates precise historical reconstructions, something that is not possible for most other alpine glaciers. The lower Grindelwald glacier remained in the area of the "Schopffelstterrassen" for a long time, approximately $600 \mathrm{~m}$ behind its greatest extent during the Little Ice Age (LIA) in 1600 and some $1250 \mathrm{~m}$ in front of its current tongue (see cover picture).

A LIA glacial minimum can be verified for the lower Grindelwald glacier, due to many high quality pictorial sources from the beginning of the $18^{\text {th }}$ century. The minimum extension is depicted in a beautiful oil painting, painted by the classicist and realist Joseph Anton Koch (1768 - 1839) (Zumbühl, 1980: 191 K.38.3 and Fig. 2). Although the ice stream does not cover the entire canvas, and although the composition makes it look "small" and visually less attractive than the tail of the glacier in the valley floor, the illuminated ice stream is actually the focal point of the picture. Koch painted this work in Rome in 1823, based on a watercolored and gouached pencil drawn nature study completed 29 years earlier (in 1794). The eastern part of the glacier ends on the lower "Schopffelsband", a good $410 \mathrm{~m}$ behind the maximum extension of the last advance from 1778/79. The western tongue of the glacier has already

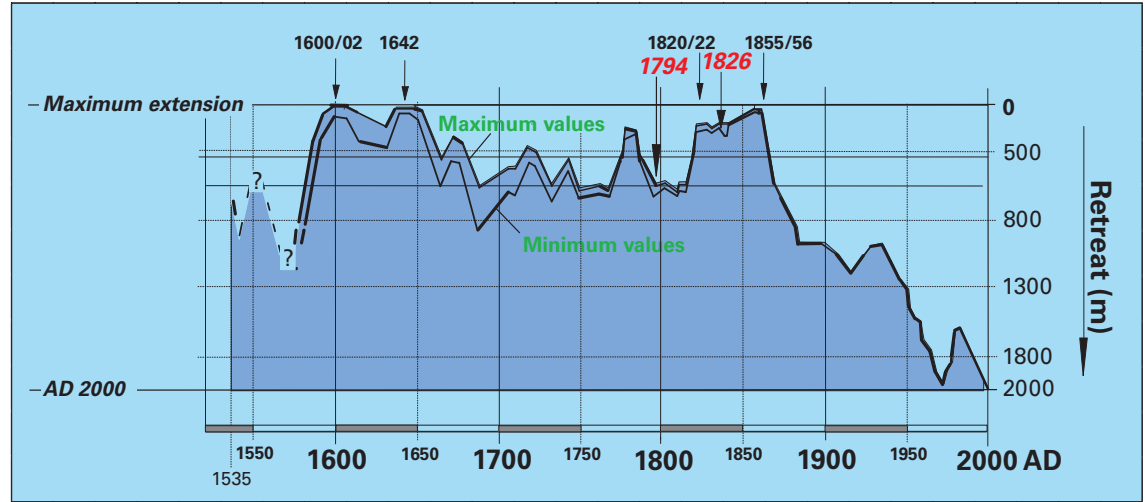

Fig. 3: Lower Grindelwald glacier: advance and retreat periods from AD 1535 - 2000 lafter Zumbühl, 1983 and Pfister et al., 1994)

retreated enough to partly reveal the mountain-facing terrace of the upper "Schopffelsen", and therefore lies a further 300-350 $\mathrm{m}$ behind the eastern glacier front. Koch painted the topography of the boulders and the glacial edge so accurately that this information could be recorded in a map (Zumbühl, 1980).

By 1808, the Lower Grindelwald glacier had retreated. This is recognizable in a fine outline etching from J. J. Biedermann (Zumbühl, 1980:192 K.46). The glacial advance from 1814 to $1820 / 22$, that led to the buildup of the glacial "tail" (a prominent ice feature that ends well ahead in the valley floor) is also well documented. In the older literature, it is reported that perhaps the glacier reached its greatest extent in the $19^{\text {th }}$ century (Zumbühl, 1980: 43). Despite these written references, in spite of pedological and dendrochronological analyses, and in spite of an analysis of the moraines pictured in the foreground, it is not possible to make a definitive statement. On the other hand, Samuel Birmann of Basel (1793-1847) has numerous watercolors from 1826 (see cover picture) that strongly argue that the maximum LIA-extent was not reached at this time. This artist's drawings constitute the most exact topographical documents that have ever depicted the glacier; they are qualitatively absolutely equivalent to photographs (Zumbühl, 1997). On Birmann's watercolored pencil drawing of September 1826, taken from the Grindelwald parsonage, the advancing lower glacier, as well as the foreground with a clearly recognizable moraine system, is beautifully depicted (Zumbühl, 1980:193 K.60; see cover picture). The ice front at that time clearly already ended behind the moraine system, although the exact distance varied. In the middle of the foreground, moraines that were probably left by the 1820/22 glacial advance can be seen. On the west side (right in the cover picture) against the "Nellenbalmfelsen", the glacier advanced less and is here at least $250 \mathrm{~m}$ behind the moraine system of an older LIA-maximum (probably from 1600/02). The fact that there is wood between the ice front and the moraines conclusively eliminates the hypothesis that there was a historic maximum extension of the lower Grindelwald glacier in 1822 (Fig. 3).

\section{REFERENCES}

Holzhauser, H., 1984: Zur Geschichte der Aletschgletscher und des Fieschergletschers. Phys. Geogr., Vol. 13, Geogr. Institut Universität Zürich.

HolzHAUSER, H. and ZUMBÜHL, H.J., 1996: To the history of the Lower Grindelwald Glacier during the last 2800 years - palaeosols, fossil wood and historical pictorial records - new results. Z. Geomorph. N. F., Suppl. Bd. 104: 95 - 127

HolzHAUSER H. und ZUMBÜHL H.J., 1999: Nacheiszeitliche Gletscherschwankungen. Blatt 3.8 des Hydrologischen Atlas der Schweiz.

Peister, C., Holzhauser, H. und ZumbüHL, H. J., 1994: Neue Ergebnisse zur Vorstossdynamik der Grindelwaldgletscher vom 14. bis zum 16. Jahrhundert. In: Mitt. Naturf. Ges. in Bern, N.F. 51, 55-79. Bern.

ZumBÜHL, H.J., 1980: Die Schwankungen der GrinSchriftquellen des 12. - 19. Jahrhunderts. Ein Beitrag zur Gletschergeschichte und Erforschung des Alpenraumes. Denkschr. Schweiz. Naturf. Ges., Bd. 92. Birkhäuser, Basel, Boston, Stuttgart, 279 pp.

ZuмвӥнL, H.J., 1997: Die Hochgebirgszeichnungen von Samuel Birmann: ihre Bedeutung für die Gletscherund Klimageschichte. In: Peter und Samuel Birmann: Künstler, Sammler, Händler, Stifter. Katalog zur Ausstellung im Kunstmuseum Basel, 27. September 1997 bis 11. Januar 1998, 59-74.

ZUMBÜHL, H. J. und HOLZHAUSER, H., 1988: Alpengletscher in der Kleinen Eiszeit. Sonderheft zum 125jährigen Jubiläum des SAC. Die Alpen, 64. Jg., 3. Quartal: 129-322. Bern. delwaldgletscher in den historischen Bild- und 


\section{Environmental Catastrophes and Recoveries in the Holocene}

London, Aug. 28 - SEPT. 2, 2002

Organised by the Department of Geography \& Earth Sciences at Brunel University, this meeting brought together 150 participants from 27 countries representing a startling range of disciplines and a myriad of topics. The majority of the delegates were geographers, geologists, archaeologists and anthropologists, usual barriers between scientific communities to forge a new mix of people was a real challenge, but one that seems to have been at the heart of the meeting's success. The broad sweep of the conference was about abrupt environmental changes that had affected the planet in the last 10,000 years, whether

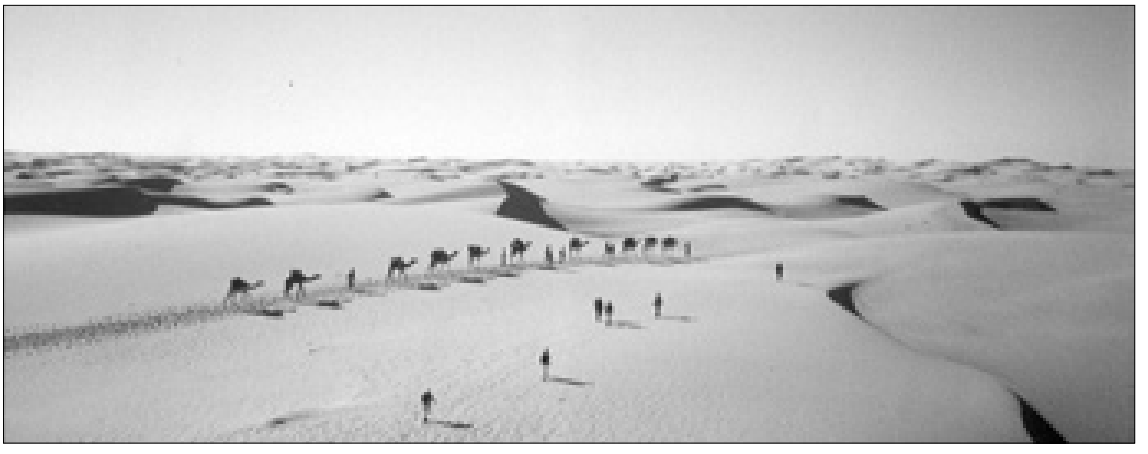

Fig. 1: Camel caravan in the Mauritanian Sahara. Camels were introduced in the Sahara around $A D$ 100. They rapidly replaced horses and oxen as the climate became drier in the following centuries (Photo: S. Leroy).

but amongst them mingled historians, astrophysicists, ecologists and health experts. Five key themes of the conference were geological, ecological, climatic, and health catastrophes and civilisation collapse. Specific topics included linkages between major volcanic eruptions recorded in the Greenland ice core with a plague in Ancient Rome, civilisation collapse in the Middle East and rainforest retraction in equatorial Africa 4000 years ago, and recent climatic downturns and the incidence of modern droughts such as that of Dustbowl America in the 1920s. Such topics ensured great media interest, with Nature, Science and New Scientist being amongst those picking up on conference highlights, such as the controversial reappraisal of the 1908Tunguska cometary impact in Siberia, new ideas on a cometary mega-tsunami that devastated eastern Australia several thousand years ago, and the politics of an earthquake fault that lies below Salt Lake City's recently constructed Olympic Stadium.

Bringing together such a rich diversity of researchers was one of the main objectives of the convenors, Professor Suzanne Leroy and Dr lain Stewart. Breaking down the

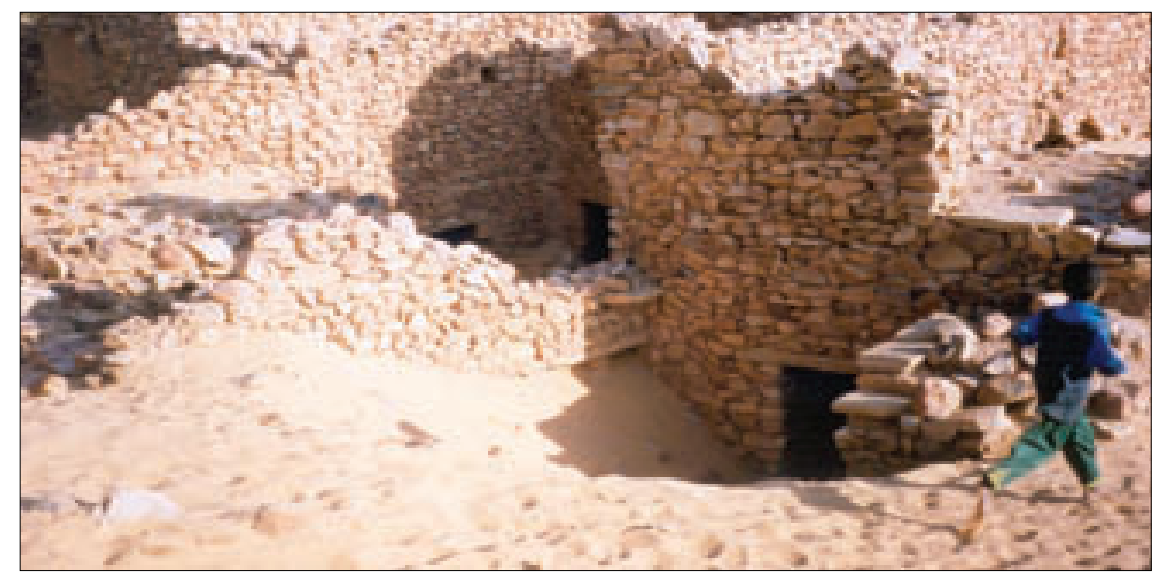

Fig. 2: Chinguetti (in the Mauritanian Sahara) is the seventh holiest city of Islam and a World Heritage site of the UNESCO since 1996. The city was created as a stop-over for the caravan trade (mostly salt). Chinguetti (XIIIth c.) was borne from the previous town of Abbere, that existed already in the VIII ${ }^{\circ}$ C. but disappeared under the sands. Chinguetti's heydays were between XVII and $X I X{ }^{\circ} \mathrm{C}$. Several levels of this ancient city are now below the sand. In the whole area, desperate measures (such as dune stabilisation by planting of hedges and reforestation by introduction of Prosopis juliflora trees) have been made, with the help of international organisations, to stop the sand invasion, but too often with little success (Photo: S. Leroy).

these changes reflected natural or The meetings sponsors included human actions and the evaluation of their impact on our past and future societies. The immediate implication of such analyses is to put in a wider time perspective the events that occur at the moment (floods, fires, hurricanes, earthquakes, epidemics, extinctions) and be ready (if possible) for the extreme ones. In stark contrast to the contemporaneous Earth Summit in Johannesburg, where the discussion was about how humans are wreaking environmental havoc PAGES, INQUA, The British Academy, IUGS-Geoindicators, and IUGS-SOTSPI.

More on our web site: http: //www.brunel.ac.uk/deptsgeo/ Catastrophes/. Abstracts are available on the website: http://atlasconferences.com/c/a/i/q/01.htm

\section{Suzanne Leroy and Iain Stewart \\ Brunel University, London UK, suzanne.leroy@brunel.ac.uk iain.stewart@brunel.ac.uk}




\title{
Workshop Reports
}

\section{Swiss NCCR Summer School}

\author{
Grindelwald, Sept. 7-14, 2002
}

The mountain resort of Grindelwald hosted the first ever Swiss NCCR (National Center for Competence in Climate Research) Summer School. Interest in the one week event was so high that two thirds of the applications had to be turned down. Along with the high mountains nearby, high expectations for stimulating sessions were clearly fulfilled, as a survey among the 80 participants and high profile lecturers from 20 countries showed.

A wide range of lectures, poster sessions, workshops and excursions was held around the central themes of "The Climate System: Past, Present and Future", "Climate Risks: Assessment, Hedging, Climate Variability" and "Predictability and Climate impacts". Topics of the 12 keynote lectures ranged from "The climate of the last millennium" (Ray Bradley, University of Massachusetts), and "The Climate System" (Thomas Stocker, University of Berne) to "Present and future climate: How sensitive is the climate" (Dennis Hartmann, University of Washington, Seattle) and "Assessing global climate change policies with computable general economic equilibrium models" (Alain Bernard, Ministry of Transport France). Arguably the most intense culture shock resulted when the traditional climate community was exposed to the work of economists - and vice versa. Talks that focused on the impact of global change on terrestrial ecosystems included "Climate change impacts on Swiss grasslands" (Jürg Fuhrer, FAL Zürich, Switzerland), "Climate change effects on agricultural crops" (Frank Ewert, University of Taastrup, Denmark), and "Global Environmental Change and Food and Fibre Production" (Peter Gregory, University of Reading).

A lot of researchers realised that colleagues specializing in very different areas were confronted with similar difficulties, mainly the need to upscale (or downscale) their findings in order to understand the big picture (or the details). For

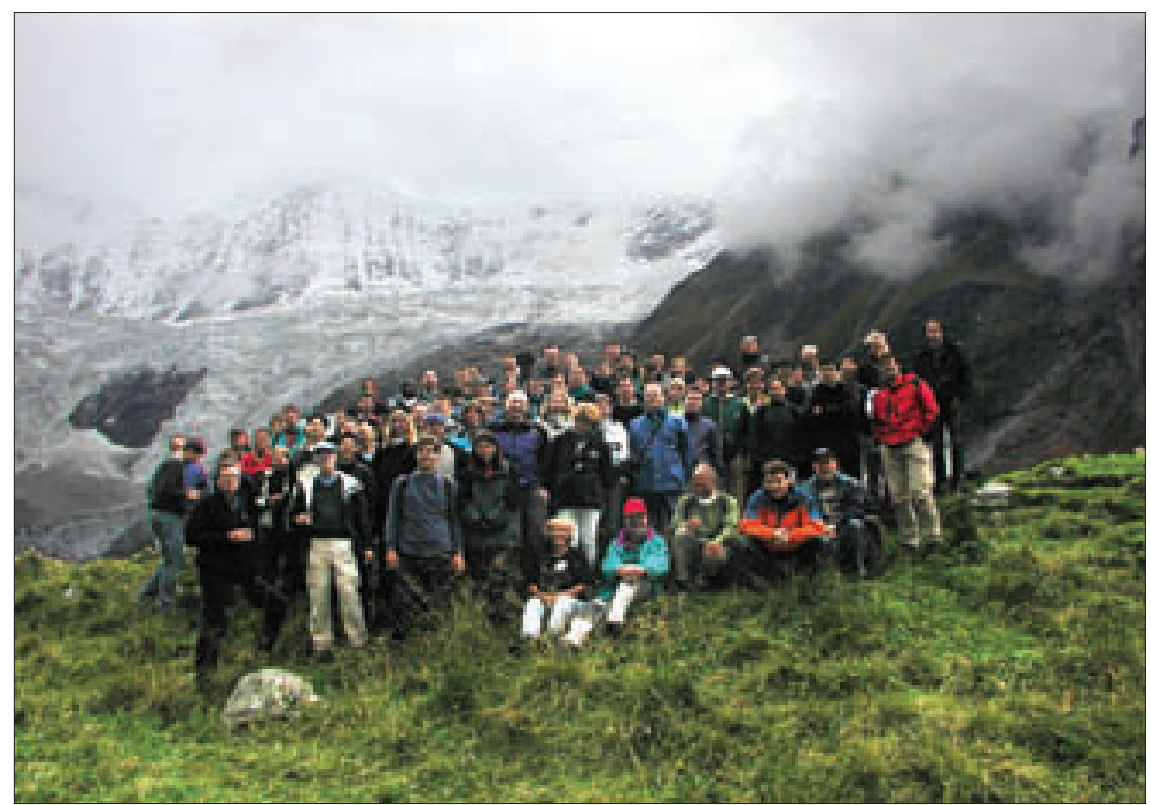

Fig. 1: Participants of the NCCR Swiss Summer School in Grindelwald on excursion to the Lower Grindelwald Glacier.

example, people dealing with ecological impacts have to find ways to upscale the biochemical reactions they observe in cells to the level of organisms, then to the level of crops, to forests and finally to the ecosystem as a whole - and the other way around. The same conceptual difficulties can be found in climate observation and climate modelling and even - this was one of this Summer Schools revelations - in a top down vs. bottom up approach in the integrated assessment of global change policies.

The Summer School explored more common ground as several speakers presented their studies on interannual to decadal climate variability. Audiences were enthralled by topics such as "El Nino/ Southern Oscillation: Observations, Mechanisms and Theory" (David Battisti, University of Washington), "Weather and Climate Variations: The Challenge of Prediction" (Huw Davies, ETH Zurich), and "Observations: Climate Modes and Dynamics (Pacific and Atlantic)" (Clara Deser, NCAR Boulder).

Finally, Heinz Wanner, University of Berne gave an introduction to the "History of Alpine Climatology and Meteorology", Christian Pfister, University of Berne talked on "Climate and Societies", Alain Haurie, Universtiy of Geneva discussed “Topdown vs Bottom-up Approaches in Integrated Assessment Modelling" and Jean-Charles Hourcade, CIRED, France gave his view on "Damage uncertainties and timing of the responses to climate change: lessons from integrated stochastic optimal control models".

The second international NCCR Summer School will take place from 30 August to 6 September 2003, again in Grindelwald, and will focus on climate change and its impacts on terrestrial ecosystems (online registration on www.nccrclimate.unibe.ch).

PAGES co-sponsored the event by financing a number of grants and by organizing a one day visit at the IPO in Bern in order to discuss possibilities to better involve young scientists in PAGES activities. The 2002 PAGES fellows were Mariano Masioskas, Argentina who was the winner of the Summer School's Blackwell poster award Jarmila Mackova,Czech Republic, Rita Pongracz, Hungary and Olga Zolina, Russia.

Kaspar Meuli,

meuli@giub.unibe.ch

NCCR Climate, University of Berne 


\section{Last PA(3E}

\section{Calendar}

March 24 - March 27, 2003, Heidelberg, Germany DEKLIM Workshop: Climate Change at the Very End of a Warmstage

Further information:

http://www.deklim.de

March 31 - April 3, 2003, Beijing, China International Symposium on Climate Change (ISCC)

Further information:

http://www.pages-igbp.org/calendar/2003/climate.html

Dr. Qin Dahe: qdh@rays.cma.gov.cn>

April 6 - April 11, Nice, France

EGS - AGU - EUG Joint Assembly;

Special PAGES-MRI-Mountain Session

Further information:

http://www.cosis.net/members/meetings/programme/ view.php?p_id=38
May 11 - May 14, 2003, Monpellier, France Climate Change: The Karst Record

Further information:

http://www.ipsl.jussieu.fr/GLACIO/KARST/Main-KRIII.html

July 23 - July 31, 2003, Reno, Nevada, USA

XVI th INQUA Congress; Special PAGES Session:

Human-Environment Interactions: Past and Present

Further information:

http://www.inqua2003.dri.edu/inqua_home.htm

0ct. 11 - 0ct. 16, 2003, San Feliu de Guixols, Spain Euresco Conference: Achieving Climate Predictability Using Paleoclimate Data. A PAGES/CLIVAR Intersection Meeting

Further information:

http://www.pages.unibe.ch/calendar/2003/euresco.html

\section{New on the PAGES Bookshelf:}

The East African Great Lakes: Limnology, Palaeolimnology and Biodiversity

ADVANCES IN GLOBAL CHANGE RESEARCH : Volume 12

Eric O. Odada and Daniel. O. Olago

Kluwer Academic Publishers, Dordrecht

Hardbound, ISBN 1-4020-0772-8

July 2002,598 pp.

EUR 150.00 / USD 138.00 / GBP 95.00

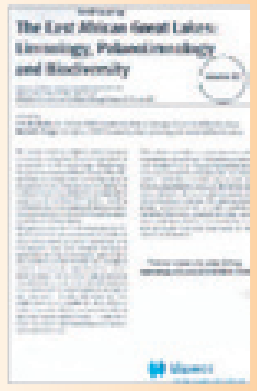

\section{Global Climate:}

Current Uncertainties in the Climate System

Xavier Rodó, Francisco A. Comín

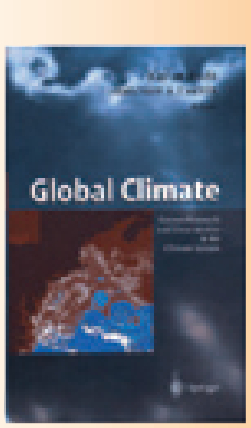

(c) Springer-Verlag

2003 | Hardback | 286 pages

ISBN: 3-540-43820-3 EUR: 89.95

Analysis of dendrochronological variability and associated natural climates in Eurasia (ADVANCE 10K)

The Holocene Special Issue (Volume 12, Issue 6, 2002)

Guest Editors: Keith R. Briffa and John A. Matthews

Arnold Publisher, ISSN 0959-6836

order info: www.arnoldpublishers.com/IntAgents.htm

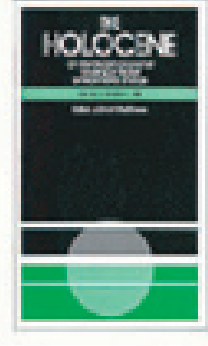

